\title{
EVOLUTIONARY ASSOCIATIONS OF BROOD PARASITIC FINCHES (VIDUA) AND THEIR HOST SPECIES: ANALYSES OF MITOCHONDRIAL DNA RESTRICTION SITES
}

\author{
Nedra K. Klein ${ }^{1}$ and Robert B. Payne ${ }^{2}$ \\ Museum of Zoology and Department of Biology, University of Michigan, Ann Arbor, Michigan 48109-1079 \\ ${ }^{2}$ E-mail: rbpayne@umich.edu
}

\begin{abstract}
The species-specific associations of the African brood parasitic finches Vidua with their estrildid finch host species may have originated by cospeciation with the host species or by later colonizations of new hosts. Predictions of these alternative models were tested in two species groups of brood parasites (indigobirds, paradise whydahs) and their hosts. Phylogenetic analyses suggested that the brood parasites and their hosts did not speciate in parallel. The parasitic indigobirds share mitochondrial haplotypes with each other, and species limits in both indigobirds and paradise whydahs do not correspond with their gene trees. Different parasite species within a region are more closely related to each other than any is to parasites that are associated with its same host species in other regions of Africa. There is little genetic difference between parasite species $\hat{D}_{i, j}<0.001$ in the indigobirds, $\hat{D}_{i, j}=0.01$ in the whydahs). Genetic distances $\hat{D}_{i, j}$ between the parasite species are less than the genetic distances between their corresponding host species in all parasite-host comparisons, and average only $7.2 \%$ as large in the indigobirds as in their hosts and $42 \%$ as large in the paradise whydahs as in their hosts. A phylogenetic model that allows ancestral haplotype polymorphisms to be retained in descendant species was compared to a constraint model of species monophyly requiring all but the one ancestral haplotype to be independently derived within each species. The constraint model increases the length of the indigobird tree by $50 \%$ over that of the model of retained ancestral polymorphisms; the difference is statistically significant. Both phylogenetic and distance analyses indicate that the brood parasites have become associated with their host species through host switches and independent colonizations of the hosts, rather than through parallel cospeciation with them. The molecular genetic results are supported by recent discoveries of additional host species that are associated with the indigobirds in the field and by variation in the species-specific song behaviors of the brood parasites.
\end{abstract}

Key words.-Brood parasitism, coevolution, cospeciation, mitochondrial DNA restriction sites, phylogeny, Vidua.

Received October 9, 1996. Accepted December 19, 1997.

In avian interspecific brood parasitism, a female of the parasitic species does not build her own nest, but lays eggs in the nests of other species, and the parasite parents neither feed nor care for their offspring. Instead, the "host" species adults raise the parasite young along with their own (Payne 1977a, 1997, 1998; Rothstein 1990). In general, birds are known for their parental care with a family bond that may last long after young are independent (Gill 1994), and parental investment of time and energy can be large. Food and care provided by host parents to parasite offspring is care denied their own young. Parasitism could thus have a severe negative impact on reproductive success of the host parents. Selection for the ability to avoid such wasted parental care effort by hosts is expected to be strong, as is selection in parasites for the ability to deceive.

Some of the known avian brood parasitic associations are specific, with a single parasite species utilizing a single host species, while others are general, such that a single parasite species utilizes many host species (Payne 1977a, 1997; Rothstein 1990). Evolutionary associations of species-specific parasites and their hosts may originate through various processes, including (1) cospeciation of the parasites with their hosts, and (2) migration and colonization by the parasites onto new species of hosts. Which mechanism has dominated the history of a parasite/host association is of inherent interest to students of such associations as well as for those interested in mechanisms of evolutionary diversification.

In this paper, we investigate the origins of species-specific

\footnotetext{
' Present address: Department of Biology, Lewis and Clark College, Portland, Oregon 97219; E-mail: nklein@lclark.edu.
}

parasite-host associations in a group of African finches. The parasites in this study are in the genus Vidua, and their hosts include various estrildid finch genera found in the Old World. The Vidua are the most species-specific of brood-parasitic birds. Each species normally is associated with one host species of estrildid finch; only two of the 19 species regularly use more than one host (Payne 1997, in press). The Vidua finches are considered most closely related to the Estrildidae, which includes the host species of the viduas (Sibley and Ahlquist 1990).

The parasite-host associations of the Vidua finches are known through field studies of behavior, song mimicry, and mouth mimicry. In most species, each male Vidua mimics the songs of only one kind of estrildid finch. For each of these species of Vidua whose behavior has been determined in the field, the finch whose song is mimicked is the host species that raises the young Vidua (C. J. Skead 1957; D. M. Skead 1975; Friedmann 1960; Nicolai 1964, 1973; M.-Y. Morel 1973; Payne 1973a, 1977a,b, 1982, 1985a,b, 1990; Payne and Payne 1994). Vidua nestlings typically mimic the mouth colors and pattern of nestlings of their host species and the two kinds of young often are reared together in the nest (Nicolai 1964; M.-Y. Morel 1973; Payne 1973a,b, 1982; Payne and Payne 1994). However, a few Vidua do not mimic their host mouths and these Vidua may be only recently differentiated species (Payne and Payne 1994). Nestling mimicry may allow the young Vidua to escape recognition and negative discrimination by their hosts, or to at least be cared for by the foster parents along with the host young. Nicolai $(1964,1974)$ suggested that it was necessary for a Vidua parasite population to match the nestling colors of its host 
due to selection over many generations and across speciation events in a process of cospeciation and coevolution. Nevertheless, coevolution can occur without cospeciation and brood parasites may have independently evolved their mimicry. This could have occurred if they colonized their hosts after host speciation and with each colonization were selected to match the mouth colors of the host nestlings. For example, parasitic cuckoos have independently evolved egg colors that match their hosts (Southern 1954; Higuchi and Sato 1984; Davies et al. 1989; Rothstein 1990), mimetic insects have independently evolved colors that match other aposematic insects (Plowright and Owen 1980; Brower 1996), and specialist herbivorous insects have switched from one host plant to another (Singer et al. 1992; Ronquist 1994; Funk et al. 1995; Radtkey and Singer 1995). Some hosts have also adapted to parasitism independently of the phylogeny of their parasites (Moore and Gotelli 1996).

Variation in the songs of the brood parasitic Vidua suggests the conditions that could lead to a switch of hosts. The young parasites learn the songs of their host species while in the care of their foster parents, and the adult parasites mimic the songs of their hosts (Nicolai 1964, 1973; Payne 1973a, 1990). A few males give the song of an alternate host species, rather than that of the normal host species. This implies that young in natural conditions are sometimes raised by an alternate host species and the potential exists to establish new breeding populations (Payne et al. 1993; Payne and Payne 1994, 1995).

The focus of this paper is to determine whether diversification within Vidua and evolution of their parasitic relationships with the estrildid finch hosts has occurred mainly through a process of host-parasite cospeciation or through independent colonizations of host species by their brood parasites.

\section{Predictions of the Two Models}

Mitter and Brooks (1983) describe two models of evolutionary association of parasites and hosts: cospeciation and independent colonization. For the brood parasitic finches, we develop each model with exclusive and strong predictions that allow its rejection, and thus a test by strong inference (Platt 1964; Hilborn and Mangel 1997).

Prediction set (1): Cospeciation Model.-(a) If the parasites and their host species are associated through cospeciation, then their evolutionary branching diagrams will be congruent because the host and parasite species diverged in parallel. (b) Brood parasites that utilize conspecific host populations in different geographic regions will be more closely related to each other than to brood parasites that parasitize different species of host in the same geographic region. (c) Pairwise genetic distances between related species of parasites will be similar in magnitude to pairwise genetic distances between their host species. (d) Pairwise genetic distances between species of parasites that each use a different host species within a region will be greater than genetic distances between populations that live in different regions but parasitize the same species of host.

Prediction set (2): Independent Colonization Model.--(a) If parasites and their host species are associated through colonization, then the evolutionary branching diagrams of par- asite and host species will not be congruent. (b) The brood parasites that live in one geographic region and parasitize different species of hosts will be more closely related to each other than to brood parasites that parasitize the same species of host in different regions. (c) Interspecific pairwise genetic distances will on average be smaller between the parasite species than between their host species (where a parasite lineage has switched from one host species to another). (d) Pairwise genetic distances between species of parasites that each use a different host species within a geographic region will be less than between brood parasites that live in different regions but parasitize the same host. This would occur where the conspecific host populations were colonized independently by different lineages of brood parasites.

Although molecular evolutionary rate heterogeneity independent of time since divergence could potentially also explain differences in genetic distance between taxa under a model of cospeciation, the comparisons of Vidua with their host species are unlikely to be dramatically influenced by this process. Host and parasite groups in this system are relatively closely related and similar in all the features typically associated with variation in molecular rates (e.g., generation times, effective population sizes, body size as it correlates with metabolic rate; Goodwin 1982; Payne 1997). Genetic distance comparisons are thus appropriate in a test of the origin of parasite-host associations in this group of birds.

Here we test the two models of evolutionary association between the brood parasites and their host species by means of phylogenetic analyses of mapped restriction sites of the mitochondrial genome and by comparison of interspecific genetic divergences in the hosts and parasites. The models were tested in two species groups of Vidua finches, the indigobirds and the paradise whydahs, and in their host species.

\section{Methods}

\section{Species and Populations}

Parasitic indigobirds ( $V$. chalybeata and others), most paradise whydahs, and their host species were collected by RBP and Laura Payne in Zimbabwe and Malawi, and by RBP, Laura Payne, and NKK in Cameroon (Payne et al. 1992, 1993; Payne and Payne 1994). As many as five species of indigobirds live in a single area with little or no interbreeding between them; in Malawi four species were taken within 50 $\mathrm{km}$ of each other. In addition to these field-collected birds, live finches were obtained from importers and avicultural sources. We refer to the area of Zimbabwe and Malawi as "S-C Africa," and Cameroon and the source area of captives for other taxa known to be from western Africa as "western Africa."

In the field, each male indigobird was tape-recorded to determine its mimicry songs. It was then captured when it came to a mist net in response to a playback of its song; birds that did not come to the net were collected with a shotgun. Paradise whydahs, the species group that parasitizes the pytilias, are not readily tape-recorded and caught in the field, so we shot male $V$. paradisaea and $V$. obtusa in Malawi. We also obtained captive birds of uncertain geographic provenance and recorded their mimicry songs before sacrificing them to obtain tissue samples: $V$. paradisaea reportedly from 
TABLE 1. Brood parasites/song mimics (Vidua species) and their corresponding host species.

\begin{tabular}{ll}
\hline \hline \multicolumn{1}{c}{ Brood parasite/song mimic } & \multicolumn{1}{c}{ Host } \\
\hline Indigobirds & Firefinches and twinspots \\
Vidua chalybeata & Lagonosticta senegala \\
V. funerea nigerrima & L. rubricata \\
V. purpurascens & L. rhodopareia \\
V. maryae* & L. sp. nov.* \\
V. larvaticola & L. larvata \\
V. wilsoni & L. rufopicta \\
V. camerunensis & L. rubricata \\
& L. rara \\
& Euschistospiza dybowskii* \\
V. codringtoni & Clytospiza monteiri \\
V. raricola & Hypargos niveoguttatus \\
V. nigeriae & Amandava subflava* \\
Paradise whydahs & Ortygospiza atricollis* \\
V. interjecta & Pytilias \\
V. togoensis* & Pytilia phoenicoptera \\
V. obtusa & P. hypogrammica \\
V. orientalis aucupum & P. afra \\
V. paradisaea & P. melba citerior \\
V. paradisaea & P. m. percivali \\
\hline
\end{tabular}

* Species lacking in phylogenetic and genetic distance analyses.

Tanzania; $V$. orientalis aucupum, which occurs in sub-Saharan West Africa; and $V$. interjecta (including a female, Payne 1991; no songs were heard from female Vidua). Museum study skins were prepared for all birds that were used in the molecular genetic analysis. Specimens were identified by comparison with other museum collections (American Museum of Natural History, AMNH; Field Museum of Natural History, FMNH; British Museum of Natural History, BMNH; National Museum of Natural History, USNM; and Museum National d'Histoire Naturelle, MNHN, Paris). Specimens are in the University of Michigan Museum of Zoology (UMMZ).

To indicate the associations of brood parasites and their host species, we list each species of Vidua and its host (Table 1 ), and the origin of specimens used in the genetic analyses (Appendix 1). Additional information on variation within some species is provided below.

Village indigobirds, $V$. chalybeata, show morphological variation (e.g., bill color) across geography. This species is widespread across sub-Saharan Africa and mimics the song of red-billed firefinch, Lagonosticta senegala, throughout its range (G. R. Morel 1959; Nicolai 1964; M.-Y. Morel 1973; Payne 1973a, 1990). One individual included in this study (\#A115, see Appendix 1) was recorded singing the song of an alternate host, L. rubricata.

Vidua codringtoni normally mimics the song of Hypargos niveoguttatus. One individual (\#A08, see Appendix 1) was recorded singing the song of an alternate host, $L$. rubricata.

Vidua camerunensis uses four host species (L. rubricata, L. rara, Clytospiza monteiri, and Euschistospiza dybowskii; Payne and Payne 1994, 1995). In addition to males whose songs we taped, we collected in Cameroon a juvenile indigobird at a call-site of an adult $V$. camerunensis that mimicked the song of the brown twinspot, Clytospiza monteiri. In Cameroon we found no wild male indigobirds that mimicked black-bellied firefinch, $L$. rara (these indigobirds occur in
Ghana; Payne 1982; Payne and Payne 1994) or that mimicked Dybowski's twinspot, Euschistospiza dybowskii (these indigobirds occur in Sierra Leone; Payne and Payne 1995).

\section{Molecular Genetic Analyses}

After birds were recorded and sacrificed, their liver, lung, heart, and pectoral muscle tissues were removed and frozen in liquid nitrogen or maintained at ambient temperature in 0.25 M EDTA/20\% DMSO buffer (Seutin et al. 1991). The frozen tissues were later stored at $-80^{\circ} \mathrm{C}$ in ultracold freezers.

Isolation, purification, and restriction endonuclease digestion of mitochondrial DNA (mtDNA) followed methods outlined in Lansman et al. (1981), Dowling et al. (1990), and Klein and Brown (1994). Purified mtDNA was isolated from liver, heart, or pectoral muscle. The amount of tissue used ranged from $0.03 \mathrm{~g}$ to $0.3 \mathrm{~g}$; the homogenization buffer consisted of one part $0.5 \mathrm{M}$ sucrose in TE to five parts $200 \mathrm{mM}$ EDTA, $10 \mathrm{mM} \mathrm{NaCl}$, and $10 \mathrm{mM}$ Tris.

Purified mtDNA was digested with 17 restriction endonucleases characterized by six-base recognition sequences: ApaI, BàmHI, BclI, BglII, BstEII, ClaI, DraI, EagI, EcoRI, HindIII, KpnI, NcoI, NdeI, NheI, PvuII, SalI, and XbaI. DNA was digested to completion (2-14 h) with an excess of enzyme under conditions recommended by the suppliers (Boehringer-Mannheim and New England Biolabs). Fragments were end-labeled with ${ }^{32} \mathrm{P}$, run in $1 \times$ TBE buffer on both agarose $(0.8-1.2 \%)$ and polyacrylamide $(3.5-5.0 \%)$ vertical gels, and visualized by autoradiography (Brown 1980). A size standard of lambda phage DNA digested with Hind III mixed with $\phi \mathrm{X} 174$ phage DNA digested with Hae III was included on each gel. Fragment sizes were estimated from calibration curves plotted from log fragment size versus distance migrated of size-standard fragments. The mean size estimate of the mtDNA molecule for all species (calculated from the sizes estimated from the mtDNA fragments generated by each enzyme) was $17.0 \mathrm{~kb}$. Size determination of fragment lengths and localization of the restriction sites is estimated to be accurate within $40-150$ base pairs (Nei 1987; Dowling et al. 1990, 1996).

Cleavage sites for each taxon were independently mapped (Appendix 2) (but with only two independent maps representing indigobirds due to the high genetic similarity among all indigobirds) using double and triple digests (Brown and Vinograd 1974; Dowling et al. 1990, 1996); 27 independent cleavage maps were generated. Restriction site homologies and restriction enzyme cleavage site losses (among individuals within a species or among indigobird individuals) relative to the mapped sites were inferred from fragment pattern comparisons with the mapped haplotypes (Vawter and Brown 1986). The positions of restriction enzyme cleavage sites that were gained relative to the mapped haplotypes were determined with additional double digests. Additional double digests were also used to verify positions of synapomorphic restriction sites in unmapped individuals.

The mapping strategy employed was to use initial double digests of all enzymes with $B g l \mathrm{II}$ and with $C l a I$ to align maps to two common restriction sites ( $\mathrm{Bgl \textrm {II }}$ site $\mathrm{A}, \mathrm{Cla}$ I site A) (Klein and Brown 1994). All mtDNA samples contained one to three BglII sites and one to three Cla I sites. Cla I site A 
appears to be conserved in finches and other songbirds examined in this lab, including the New World honeycreepers and warblers Coereba, Dendroica, Setophaga, Geothlypis, $\mathrm{Pa}$ rula, and Basileuterus (Klein and Brown 1994; Seutin et al. 1994), as well as in chicken, Gallus gallus, where the entire mitochondrial genome has been sequenced (Desjardins and Morais 1990). Homology of the Cla I site A in finches was confirmed by its constant position relative to the two Sac II sites that mark a 1.72-kb fragment and are conserved among vertebrate mtDNAs (Brown 1985; Carr et al. 1987; Moritz et al. 1987; Desjardins and Morais 1990). One Sac II site is located within the $12 \mathrm{~s}$ ribosomal RNA (rRNA) gene, the other is in the 16s rRNA gene (Hixson and Brown 1986; Desjardins and Morais 1990). Cla I cleaved this 1.72-kb fragment into 1.4-kb and $0.32-\mathrm{kb}$ fragments in all but one of the finches examined (this Cla I site A was absent in one L. rara (\#036), for which the map was aligned with other maps using $B g l$ II site A and the two Sac II sites). A Cla I site occurs in the chicken mtDNA sequence between the Sac II sites, 332 bp (within the range of measurement error of the 320-bp fragment determined in the finch mtDNAs) from the Sac II site in the $12 s$ rRNA gene. Additional double and triple digests with other enzyme combinations were then used to determine more precisely the map positions of sites not determined by double digests with $B g l \mathrm{II}$ and $\mathrm{Cla}$ I. Restriction site data were incomplete in some cases (Appendix 3).

In total, 200 restriction sites were mapped in the finches surveyed (Appendix 2), including captives not used in further analyses. This sample accounts for approximately $7.1 \%$ of the $17-\mathrm{kb}$ mitochondrial genome.

\section{Analyses of Phylogenetic Relationships and Genetic Distances}

The phylogenetic estimation program PAUP version 3.1.1 (Swofford 1993) was used to generate hypotheses of relationship from the matrix of restriction site presence/absence. Genetic distances were calculated with PAUP* version 4.0d49. For phylogeny estimation, characters were treated as unordered. Haplotypes defined as unique associations of restriction sites were the units of analysis (taxa) except that an additional analysis of relationships within Vidua was done treating individual indigobirds as taxa.

Phylogenetic Analysis of Relationships within Vidua.-To test the relationships within the species complexes of the indigobirds and the paradise whydahs, and whether these two species groups each were monophyletic, we estimated the phylogenetic relationships among all Vidua. We used the entire species assemblage of Vidua as available (we lacked two of the 19 species: an indigobird $V$. maryae and a paradise whydah $V$. togoensis).

The following estrildid finches were included as outgroups for rooting the phylogenetic tree: (1) cut-throat finch, Amadina fasciata, a species that in another molecular genetics study (Kakizawa and Watada 1985) was determined to represent the basal split of the set of African estrildid finches that includes all host species of the viduas; (2) orange-winged pytilia, Pytilia afra, a host of the paradise whydahs; (3) redbilled firefinch, Lagonosticta senegala, a host of the indi- gobirds; and (4) green twinspot, Mandingoa nitidula, which is not known to be a host.

We carried out heuristic searches using the random addition sequence and tree bisection-reconnection branch swapping options. Because there were so many taxa, we completed 30,000 heuristic searches in which only one tree of 273 steps or less was saved from each search. This search strategy allowed us to visit many islands of trees (Swofford 1993, p. 34). Heuristic (50 replicates) and exhaustive searches were also done for the paradise whydahs using $V$. macroura as the outgroup. This resulted in a nearly identical topology as that generated in the heuristic search that included all Vidua.

Phylogenetic Analysis of Relationships within the Host Groups.-We completed 50 heuristic searches for each host group using the tree bisection-reconnection and random addition sequence options. Mandingoa nitidula was included as the outgroup for the analysis of relationships within the firefinch-twinspot host group, and Amadina fasciata was included as the outgroup in the analysis of relationships within the Pytilia host group. We also completed an exhaustive search for the Pytilia analysis, and a branch-and-bound search for the firefinches-twinspots. The same sets of trees were found as in the heuristic searches.

Because large amounts of missing data can yield many equally most-parsimonious trees, we repeated the analysis excluding those taxa with missing data for more than one enzyme. For the Vidua analysis this also resulted in a large number of equally most-parsimonious trees and essentially the same consensus tree as when all taxa were included. For the firefinch-twinspot analysis, 16 shortest trees were generated and the consensus of these showed the same relationships among the remaining taxa as did the consensus of shortest trees generated when all taxa were included.

Statistical Tests of Differences between the Shortest Vidua Tree and Constrained Trees.-Three types of constraint analyses were done with heuristic searches, all using the complete Vidua dataset: (1) paradise whydah relationships constrained to match the topology of their Pytilia hosts; (2) each individual indigobird included as a taxon on the Vidua tree and constrained such that each species in S-C Africa was monophyletic; and (3) each individual indigobird included as a taxon on the Vidua tree and constrained such that each species in Cameroon and each song form of $V$. camerunensis was monophyletic. Differences between the shortest Vidua tree and the constrained trees were tested with the Wilcoxon signed-rank test (Templeton 1983). The analysis was conducted as a one-tailed test and the test statistic used was $T^{-}$, the sum of the negative ranks. Tree number one from each search was arbitrarily chosen as the one to use in the statistical comparisons.

Analysis of Genetic Distances.-The genetic distance between pairs of haplotypes was estimated from the proportion of shared restriction sites, as shown in the matrix of adjusted mean pairwise differences in the PAUP analyses. This adjusted mean difference value excluded sites where presence or absence was not determined for both members of the pair. Genetic distances in terms of restriction sites that are shared between species were estimated from the mean distances of all haplotypes identified in each of the two species compared (mean of the values for all haplotypes for both species; Table 
TABLE 2. Mean genetic distances between species of Vidua brood parasites and between their hosts. Between-species comparisons were made among the Vidua within each region and among the host species within each region. All values as calculated from mean adjusted distances from PAUP; $\hat{d}_{i, j}=$ Nei's $(1987) \hat{D}_{m}$.

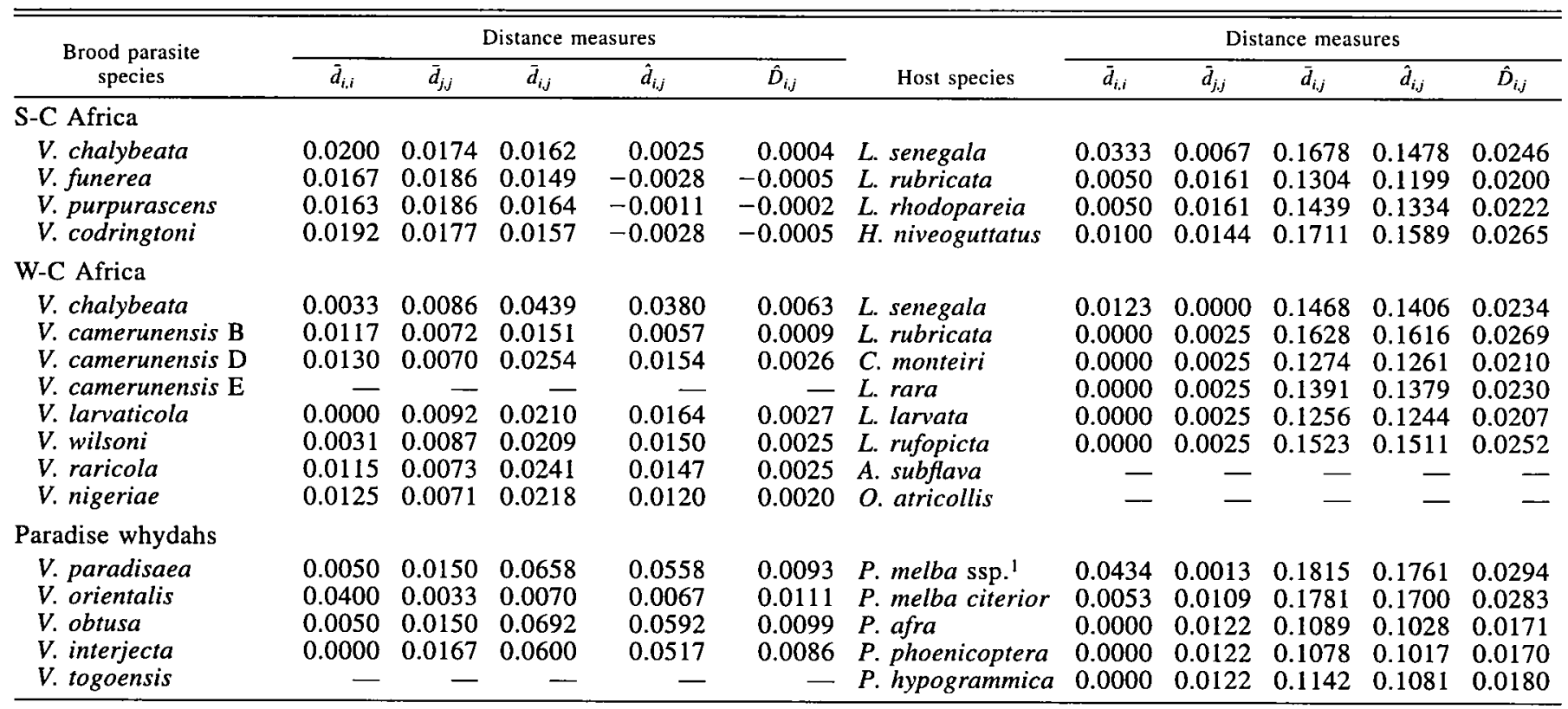

'Pytilia melba grotei and $P$. m. percivali, subspecies in range of Vidua paradisaea.

Notation: $n_{i}=$ number of haplotypes within a taxon $i ; n$ of pairwise comparisons is described by the expression for combinations $n C r$, where $r=2$, and $n=$ the number of different haplotypes: $n C r=n ! / 2(n-2) ! ; n_{j}=$ number of haplotypes within a taxon $j$; then $n$ of pairwise comparisons between taxa $i$ and $j=n_{i} n_{j}$

$\hat{d}_{i, j}=\frac{\Sigma\left[\bar{d}_{i, j}-0.5\left(\bar{d}_{i, i}+\bar{d}_{j, j}\right)\right]}{n}$

$\bar{d}_{i, i}=$ mean restriction site difference between haplotypes within a taxon $i ; \bar{d}_{i, j}=$ mean pairwise restriction site difference of haplotypes between any two taxa $i, j ; \hat{d}_{i, j}=$ mean net restriction site difference between taxon $i$ and all other compared taxa $j ; \hat{D}_{i, j}=\left(\hat{d}_{i, j}\right) / 6=$ mean nucleotide genetic difference between taxon $i$ and all other compared taxa $j$.

2). Because some species had more than one haplotype, and some haplotypes were shared among species, we adjusted the mean between-species variation by the mean genetic distance within a species, as indicated by the two-parameter model of Nei $(1987$, p. 223). Mean net interspecific distances were calculated from all pairwise interspecific comparisons of haplotypes within each parasite group and each host group, where each was compared with all other species in the corresponding group. For the indigobirds and their hosts the comparisons were made only within the same geographic region of Africa. The distance estimates included pairwise $d_{i, j}=0$ where haplotypes did not differ between two species. Because of the small sample (most haplotypes were represented by only one individual per species, though haplotypes were often shared among species), we did not adjust the distances between species for the frequency of haplotypes within each species, but rather we weighted each haplotype equally in the estimate of genetic distances within and between species. We did not estimate an error term (Nei and Tajima 1983; Nei 1987) for distances between species, as sample sizes of individuals within a species were small.

Genetic distances in terms of nucleotides were estimated by dividing the restriction site distance generated in PAUP version $4.0 \mathrm{~d} 49$ by the number of bases involved in each restriction enzyme ( $n=6$ for all restriction enzymes in the survey). This estimate allows a transformation of the restriction site distance to an estimate of nucleotide sequence dis- tance (Nei 1987). The estimate assumes a single nucleotide difference when a restriction site is gained or lost from an ancestral condition, and we restricted the analysis to birds that are thought to be closely related to avoid the complication of multiple changes within a site (Nei 1987; Dowling et al. 1996). As the likelihood of multiple substitutions of nucleotides within a site is higher within the species groups that are less closely related and have higher interspecific genetic distances, the values of estimated genetic distance will underestimate the distances between the host species, which were greater than those between the brood parasite species.

\section{RESULTS}

\section{Phylogenetic Relationships within the Vidua Finches}

The 12,675 shortest trees of 270 steps each are summarized in the strict consensus tree (Fig. 1), which illustrates that Vidua are monophyletic with respect to the estrildids included as outgroups and are thus more closely related to each other than any is to the corresponding host species groups. The indigobirds and the paradise whydahs also each comprise a monophyletic group within the Vidua assemblage. The demonstration of monophyly for each of the two species groups of interest allows us to test the relationships within each group. However, examination of branching diagrams depicting relationships within the paradise whydahs and the indi- 


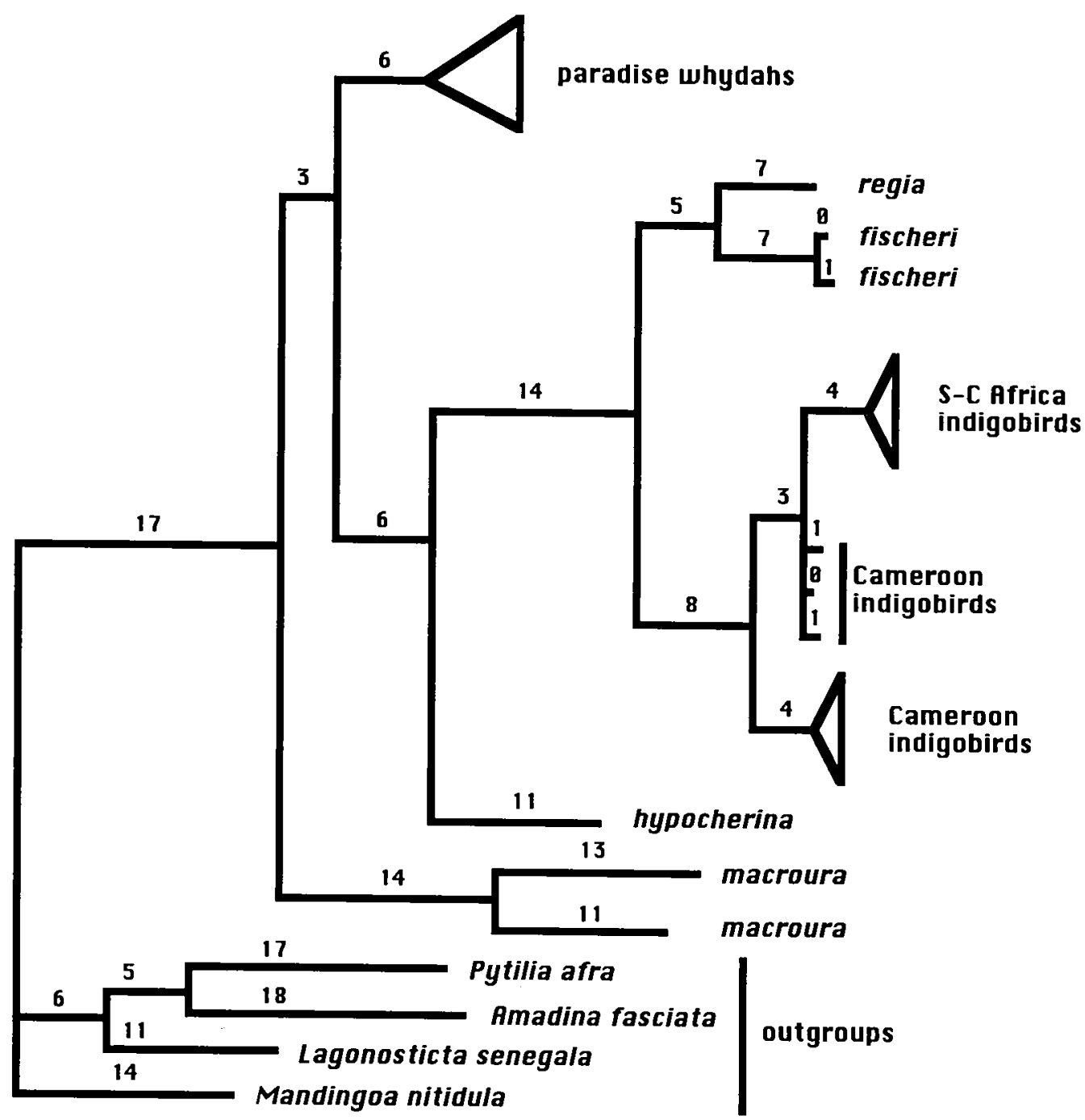

FIG. 1. Strict consensus of 12,675 trees, 270 steps each, showing higher-level relationships among the mtDNA restriction site haplotypes of the Vidua finches, with four estrildid finches as the outgroups $(\mathrm{CI}=0.544$ excluding phylogenetically uninformative characters and $\mathrm{RI}=0.841)$. Numbers above branches represent number of restriction site differences from the node, as determined under the accelerated transformation (ACCTRAN) character state optimization option in PAUP 3.1.1, and branch lengths are proportional to these numbers.

gobirds reveals a general lack of species monophyly of mtDNA lineages, especially in the indigobirds (Figs. 2, 3).

\section{Phylogenetic Comparisons of Brood Parasite Species and Their Hosts}

The branching diagrams of the pytilias and of the paradise whydahs are not congruent (Fig. 2). The whydahs, $V$. orientalis, that are associated with melba finches in western Africa are not most closely related to the whydahs, $V$. paradisaea, that are associated with melba finches in eastern and southern Africa. Each is instead more closely associated with another species of paradise whydah in the same geographic region, $V$. orientalis with $V$. interjecta, and $V$. paradisaea with $V$. obtusa. In contrast, the melba finches, Pytilia melba, of southern and eastern Africa ( $P . m$. grotei, $P . m$. percivali hosts of $V$. paradisaea) and of western Africa $(P . m$. citerior hosts of $V$. orientalis) are each other's closest relatives, and the geographic replacements $P$. afra in S-C Africa and the two $P$. phoenicoptera and $P$. hypogrammica in western Africa are sister taxa. The differences between a shortest Vidua tree (270 steps) and one of the trees constrained so that whydah branching patterns matched those of their hosts (283 steps) were statistically significant ( $\left.n=19, T^{-}=-30.0, p<0.005\right)$. In addition to the incongruence of sister group relationships in the paradise whydahs and their hosts, the whydahs $V$. orientalis and $V$. interjecta do not have mutually exclusive mitochondrial lineages. Also, in the analysis that included all Vidua and outgroup species the lineages of $V$. paradisaea and $V$. obtusa are not fully resolved to species. The phylogenetic estimates thus indicate that the whydahs have not cospeciated with their host species.

The trees for indigobirds and their host species are even more compelling in their lack of evidence for cospeciation of hosts and brood parasites (Fig. 3). For the indigobirds, the associations of brood parasites are with geographic regions rather than with their host species. It is also not possible to 
Pytilia - hosts

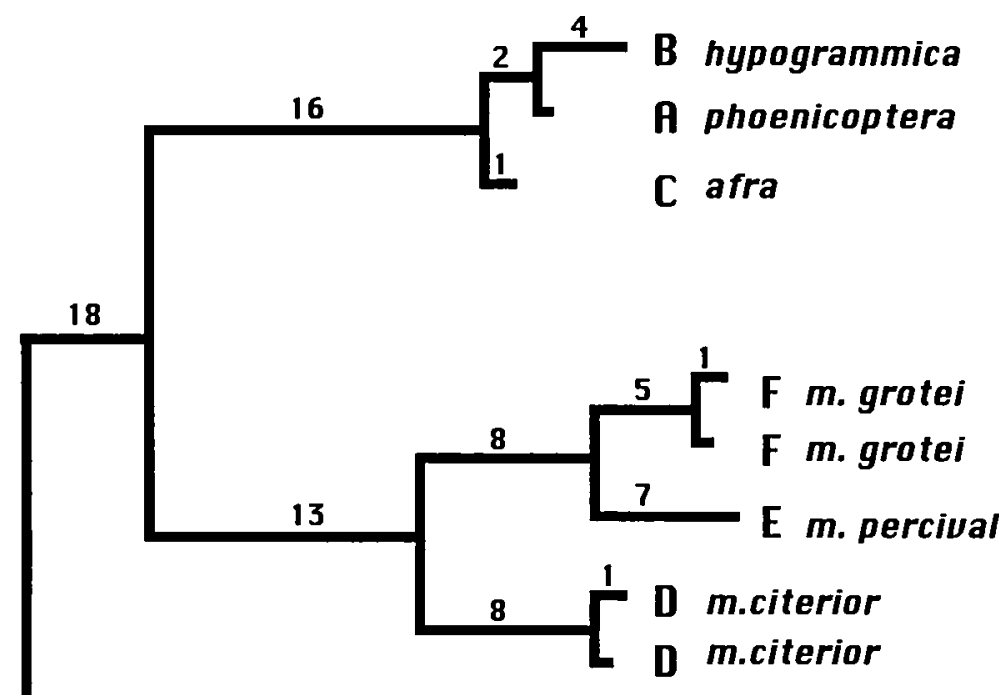

Amadina fasciata (outgroup)
Vidua - parasites (paradise whydahs)

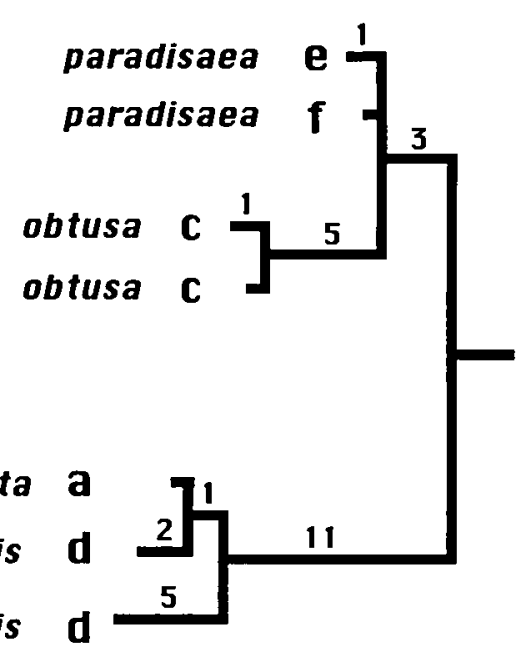

\section{Capital letter designates host takon and corresponding small letter designates its brood parasite}

FIG. 2. Phylogenetic estimates of relationships within the pytilias Pytilia and within their brood parasites, the paradise whydahs (enlarged from Fig. 1 to depict lower-level relationships). Pytilia relationships are shown as the single most-parsimonious tree of 84 steps, CI = 0.810 excluding phylogenetically uninformative characters, and RI $=0.885$. Numbers above branches represent number of restriction site differences from the node as determined under the accelerated transformation (ACCTRAN) character state optimization option in PAUP 3.1.1, and branch lengths other than that between the outgroup and ingroup node are proportional to these numbers. Each host species is assigned a capital letter and its brood parasite species is assigned the corresponding lowercase letter. Note that $\mathrm{e}=V$. paradisaea song mimics of Pytilia melba percivali $(\mathrm{E})$, and $\mathrm{f}=V$. paradisaea song mimics of $P$. melba grotei $(\mathrm{F})$. The whydah $(V$. togoensis) that parasitizes Pytilia hypogrammica (B) was not available for phylogenetic analysis.

differentiate the morphologically distinct indigobird species by their restriction site profiles, even though they differ consistently in plumage (except $V$. funerea and $V$.purpurascens), song, and mouth colors of the young (Payne 1973a; Payne et al. 1992, 1993; Payne and Payne 1994). The inability to distinguish indigobird species based on mtDNA haplotypes is due to the extreme similarity of haplotypes (mean difference between haplotypes within a geographic area was gain/ loss of two restriction sites), and to a nonhierarchical pattern of restriction site gains and losses.

Within the Vidua indigobirds, two main mtDNA clades are apparent, one for the four species in Malawi and Zimbabwe (S-C Africa) and one for the four species (excluding $V$. chalybeata) in Cameroon. Within each of these regions, the mitochondrial haplotypes do not separate by species of Vidua. Instead, some restriction site haplotypes are shared across species. In S-C Africa the 12 haplotypes form a lineage that is shared among four species of indigobirds, one haplotype is shared by all four species, and two haplotypes are shared by two species. In Cameroon 12 haplotypes form a lineage that includes all species except $V$. chalybeata, one haplotype is shared by three species, and three haplotypes are shared by two species.
Within the hosts of the indigobirds, Peters' twinspot, $H y$ pargos niveoguttatus, is less closely related to the firefinches than they are to each other, and brown twinspot, Clytospiza monteiri, is more closely associated with the firefinches than with the other twinspot (though its restriction sites were incompletely sampled). Where two or more haplotypes were sampled within a species (L. senegala, L. rara, L. rubricata, L. rhodopareia, $H$. niveoguttatus), the sets of haplotypes were not shared between species, and geographically replacing subspecific forms within the species $L$. senegala and $L$. rubricata each were each others' closest relatives.

\section{Shared Haplotypes among Species}

The extensive sharing of haplotypes among species of indigobirds might be due either to shared ancestral polymorphisms, to hybridization and introgression of mtDNA between species, or to an independent origin of restriction sites within each species. We evaluated the origin of the shared polymorphisms versus independent origin of restriction sites by testing the effect on the number of steps that would be involved in each model. The model of shared ancestral polymorphisms involved the minimal number of steps estimated 


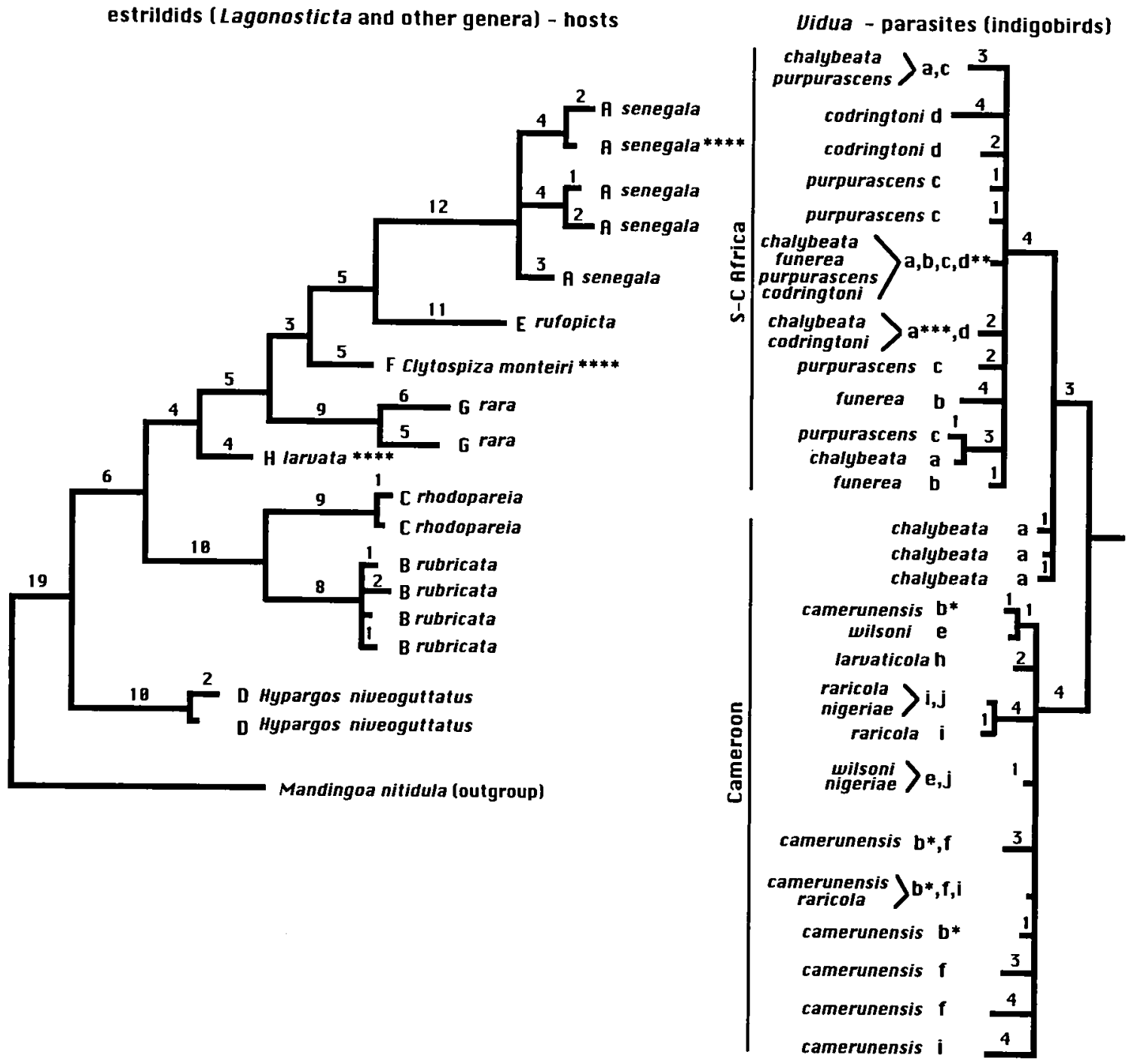

Capital letter designates host takon and corresponding small letter designates its brood parasite

FIG. 3. Phylogenetic estimates of relationships within the estrildids (firefinches Lagonosticta spp. plus twinspots Hypargos niveoguttatus and Clytospiza monteiri), and within their brood parasites, the indigobirds (enlarged from Fig. 1 to depict lower-level relationships). The estrildid tree shown is a strict consensus of 12 equally most-parsimonious trees, each of 152 steps with CI $=0.571$ excluding phylogenetically uninformative characters and RI $=0.792$. Each host species is assigned a capital letter and its brood parasite species is assigned the corresponding lowercase letter. Numbers above branches represent number of restriction site differences from the node as determined under the accelerated transformation (ACCTRAN) character state optimization option in PAUP 3.1.1; branch lengths other than that between the outgroup and ingroup node are proportional to these numbers. All species on the estrildid tree are Lagonosticta spp. unless otherwise noted. Each branch on the indigobird tree represents a different restriction site haplotype, and some of these were found in more than one species of indigobird. The species identifications for the indigobirds are: a $=$ Vidua chalybeata, a*** $=V$. chalybeata song mimic of $L$. rubricata, $\mathrm{b}=V$. funerea, $\mathrm{b}^{*}=V$. camerunensis song mimics of Lagonosticta rubricata, $\mathrm{c}=V$. purpurascens, $\mathrm{d}=V$. codringtoni, $\mathrm{d}^{* *}=V$. codringtoni song mimic of $L$. rubricata, $\mathrm{e}=V$. wilsoni, $\mathrm{f}=V$. camerunensis, $\mathrm{h}=V$. larvaticola, $\mathrm{i}=V$. raricola (host Amandava subflava not available for phylogenetic analysis), $\mathrm{j}=V$. nigeriae (host Ortygospiza atricollis not available for phylogenetic analysis). Both $\mathrm{a}^{* * *}$ and $\mathrm{d}^{* *}$ are examples of apparent host-switching, which is consistent with the colonization hypothesis. The usual host of $V$. chalybeata (a) is Lagonosticta senegala (A) and the usual host of $V$. codringtoni (d) is Hypargos niveoguttatus (D). $* * * *=$ Branch lengths for Clytospiza, L. larvata, and one of the Lagonosticta senegala (\#A171) are not accurate due to the large number of missing data.

in the distribution of haplotypes in the sample; the model of independent origins of the same restriction site haplotypes added to the number of steps that would be involved in describing their distribution when we constrained each species to be monophyletic in terms of its mtDNA haplotypes. The minimal number of steps in the tree for the $22 \mathrm{~S}-\mathrm{C}$ African birds was 18. When individuals in S-C Africa were constrained to cluster as monophyletic species groups the tree was 28 steps, an increase in length of $56 \%$. This difference was statistically significant $\left(n=10, T^{-}=4.5, P<0.01\right)$ The minimal number of steps for the 23 birds taken in Cameroon was 26; when the species were constrained and the 
song forms of $V$. camerunensis were considered as separate entities, the resulting tree was 38 steps, an increase of $46 \%$. This difference was also statistically significant $\left(n=17, T^{-}\right.$ $=36.5, P<0.05)$. The large increase in the estimate of the number of steps when not allowing ancestral polymorphisms to be retained leads us to consider a retention of ancestral polymorphisms as the more parsimonious explanation (relative to independent origin of restriction sites within species) for the shared haplotypes among the species of indigobirds.

\section{Genetic Distances}

Mean genetic distances between parasite species in both groups were less than mean distances between their host species (Table 2). Within the paradise whydahs the mean was $42 \%$ of that between the pytilias. In the indigobirds there were larger between-haplotype genetic distances within a species than between species in six of the nine regional populations where two or more haplotypes were sampled. Within the indigobird group from Malawi and Zimbabwe, the estimated mean genetic distance between species $\hat{d}_{i, j}$ was thus sometimes less than zero because the within-species distance was greater than the between-species distance. Where estimates of $\hat{D}_{i, j}<0.001$ are adjusted to 0.001 , the mean genetic distance between indigobird species in Malawi and Zimbabwe was $0.9 \%$ of the mean distance between their host species in that region. In Cameroon, the mean genetic distance between five indigobird populations was $13 \%$ that of their five host species; the larger $\hat{d}_{i,-}$ estimates for these indigobirds relative to those in Malawi and Zimbabwe involved Cameroon $V$. chalybeata, which did not share haplotypes with the other species. Combining estimates, the mean genetic distance between the indigobirds was only $7.3 \%$ as large as the mean genetic distance between their host species in the same regions.

In all 13 pairwise comparisons of brood parasite and their host species, the genetic distance between the parasite species (for the indigobirds, compared within a region) is less than the genetic distance between their corresponding host species. This was true both for the estimates uncorrected for within-species variation $\left(\bar{d}_{i, j}\right)$ and for the net estimates that take into account the within-species variation $\left(\hat{D}_{i, j}\right)$ (Table 2$)$. The probability that the observed distribution is explained by an equal proportion of hosts and parasites with the larger genetic distance can be estimated with a binomial distribution, where the factorial expression gives an estimate $P=$ 0.00012 . The low probability allows us to reject the model of cospeciation and to accept the alternative model of colonization of the host species after the host species had differentiated and speciation of parasites after hosts.

In addition, the genetic distances between geographic replacements of indigobirds that parasitize the same host species in different regions of Africa were about the same or greater than the genetic distances between different indigobird species (which each parasitizes a different host) within a region. The $\left(\hat{D}_{i, j}\right)$ between $V$. chalybeata (song mimics and brood parasites of red-billed firefinch, L. senegala), in Cameroon and those in S-C Africa was 0.0019 , whereas between $V$. chalybeata and the other indigobird species within a region $\hat{D}_{i, j}$ was 0.0063 in Cameroon and 0.0004 in S-C Africa. $\hat{D}_{i, j}$ between the Vidua song mimics of African firefinch, $L$. rubricata, in Cameroon and the song mimics of this firefinch in S-C Africa was 0.0092 , whereas between different song mimics within a region $\hat{D}_{i, j}$ was -0.0005 in S-C Africa and 0.0009 in Cameroon. The greater genetic distances between Vidua that are associated with the same host in different regions than between local Vidua with different species of hosts within a region is consistent with a model of independent colonizations of the host species from a local source, in particular with the indigobirds that are associated with African firefinch, $L$. rubricata.

\section{Discussion}

\section{Cospeciation, Colonization, and the Origins of Brood Parasite-Host Associations}

A preliminary comparison of the Vidua brood parasite and host species (Klein et al. 1993) used restriction fragment length polymorphisms rather than the mapped restriction sites, which allow a spatial criterion of homology. In both, the estimates of relationships among the brood parasites are not congruent with the estimates of relationships among the host species. The lack of parallel speciation is also apparent in a quantitative comparison of the trees of these brood parasites and their hosts (Page 1994). Although the restriction fragment studies did not take into account the within-species genetic variation, both studies gave similar results: the brood parasites were genetically more similar to each other than were their host species and the differences were an order of magnitude lower in the brood parasitic indigobirds.

The molecular genetic analyses thus support the colonization model rather than the cospeciation model. Each of the predictions of the model of independent colonization was supported by the molecular results. (a) The branching diagrams of the Vidua mtDNAs do not parallel the branching diagrams of their host species' mtDNAs. (b) The branching sets for indigobirds are more closely associated with geographic regions. (c) Similarity of mtDNAs is much greater among the brood parasites than among their host species. (d) Genetic distances between species of brood parasite sampled from within a geographic region were smaller than distances between parasitic individuals that use the same species of host in different geographic regions. The much smaller genetic distances between species of brood parasite than between host species suggest a more recent speciation in the Vidua parasites than in their hosts. The results indicate that the brood parasites have associated with new host species by colonization, learned their songs, and then later matched the colors and patterns of the host nestlings' mouths only after many generations of selection for mimicry during periods of competition between the parasite and host nestlings.

The diversity of host species of estrildid finches that are associated with the indigobirds is consistent with a colonization model of association. Early observations indicated that the indigobirds were associated only with the firefinches $L a$ gonosticta (Nicolai 1964; Payne 1973a, 1982). They are now known also to be associated with other species groups. Certain indigobirds mimic the songs and are associated with twinspots in three other estrildid genera (Hypargos, Clytospiza, and Euschistospiza; Payne et al. 1993; Payne and Payne 1994, 1995). In western Africa including Cameroon, one indigobird species 
is associated with Amandava subflava goldbreast and another is associated with Ortygospiza atricollis quail-finch (Payne and Payne 1994); neither host is closely related to firefinches or twinspots (Goodwin 1982; Kakizawa and Watada 1985; Wolters 1987). Some populations of $V$. camerunensis are associated with brown twinspot or Dybowski's twinspot, and others are associated with the firefinches $L$. rara or $L$. rubricata (Payne and Payne 1994, 1995). The greater variation in behavior and morphology among the host species than among the indigobirds (Payne 1973a; Goodwin 1982; Payne and Payne 1994) also suggests that a series of colonizations occurred well after the time of the host species divergence.

The behavior of the Vidua is consistent with a colonization model. In the field, occasional males (1\% of 484 males, in areas where two or more species of indigobirds live together) have songs mimicking a species of estrildid that is not the normal host of this species of indigobird (Payne et al. 1993). Two of those birds were included in our restriction sites analysis: a $V$. codringtoni that mimicked the songs of African firefinch $L$. rubricata instead of the usual host, the twinspot $H$. niveoguttatus, and a $V$. chalybeata that mimicked songs of $L$. rubricata rather than the usual host, $L$. senegala (Appendix 1). Neither indigobird mimicked any of the songs of its usual host species. Two other indigobirds with songs of alternate host species were both $V$. chalybeata that mimicked songs of Jameson's firefinch, L. rhodopareia (Payne 1973a; Payne et al. 1993). Their songs indicate that these males were reared by the alternate host species and not by their normal host.

Second, in fostering experiments the indigobirds that were raised by an alternate species, the Bengalese finch, Lonchura striata, copied the Lonchura song and not that of their normal firefinch host (Payne et al., in press). An implication is that this behavior allows a switch from one host species to another. The switch of a brood-parasitic female could found a population where descendant males mimic the new host species, females are attracted to males with this song, and females are imprinted on their foster parents and return to lay their eggs in the new foster species' nests (Payne 1973a, 1982).

Vidua nestlings in the nest of such a new host may be disadvantaged in receiving parental care, but mouth mimicry of their foster species' nestlings is not necessary insofar as their survival in the brood may vary with the social and feeding conditions. Nicolai (1964) found that nesting estrildids in captivity often do not rear the young of species except their own, but he noted that sometimes they accept or adopt the young of other species. Goodwin $(1960,1982)$ noted that some parents desert their young, whereas others rear not only their own but also other species. Immelmann et al. (1977) compared the growth of nestling zebra finches, Taeniopygia guttata, of two kinds: (1) nestlings (normal plumage) with pigmented mouth markings; and (2) nestlings that lack the markings. Normal nestlings received more food from the parents, had priority to first feeds of the day, grew faster, and had higher survival. In two additional studies comparing normal and unmarked nestlings, the unmarked young grew more slowly when food was limited, but there was no difference when food was abundant and there was no difference in survival (Skagen 1988); the survival of unmarked nestlings was lower when food was limited, but equal when food was abundant (Reed and Freeman 1991). The experiments in this finch suggest the conditions when a nestling brood parasite will survive in the brood of a new species of host whose own nestlings have a different mouth pattern.

\section{Species Trees, Gene Trees, and the Distribution of mtDNA Haplotypes}

Mitochondrial DNA haplotypes are shared among indigobirds that are recognizable both as distinct morphologically diagnostic phylogenetic species and as biological species or intrabreeding populations (Payne et al. 1993). A lack of difference or a very low genetic distance $(<1 \%)$ in molecular genetic profiles between species has also been reported in a few other birds (Kessler and Avise 1984; Shields and Helm-Bychowski 1988; Avise et al. 1990; Zink et al. 1991; Seutin et al. 1995). The sharing of haplotypes can be interpreted as due to (1) genetic polymorphisms that are retained from an ancestral population (Tajima 1983; Moran and Kornfield 1993; Avise 1994; Moore 1995); (2) independent gains or losses of certain restriction sites in different lineages (Aquadro and Greenberg 1983; Templeton 1983; Moritz et al. 1987); or (3) hybridization and introgression of mtDNA between species (Moritz et al. 1992; G. R. Smith 1992; Avise 1994; Moore 1995).

The large amount of genetic polymorphism within a species and the distribution of shared haplotypes among species of indigobirds within a geographic region is consistent with a history of retained ancestral polymorphisms within very recently diverged descendant species (Golding 1992; Avise 1994). A hypothesis of recently diverged indigobird species is also supported by their low between-species genetic variation when compared with the paradise whydahs, the estrildids included in this study, and other songbirds (Edwards and Wilson 1990; Johnson and Cicero 1991; E. F. G. Smith et al. 1991; Zink et al. 1991; Richman and Price 1992; Seutin et al. 1995). The lack of congruence between species trees and the mitochondrial-gene trees, the parsimonious accounting for shared haplotypes in a model of ancestral polymorphisms, and the occurrence of shared haplotypes among species within a geographic region all indicate that these species retain a set of ancestral polymorphisms that have not had time to become differentially lost through the stochastic lineage sorting process.

As an alternative to colonization, a hypothesis of cospeciation and subsequent hybridization could account for the observed sharing of haplotypes among the species of indigobirds. This hypothesis might be supported if haplotypes were shared between phylogenetically remote lineages of species (Moritz et al. 1992; G. R. Smith 1992; Moore 1995), that is, if there were any cases of large genetic distances (similar to levels found in host species) between mtDNA haplotypes within the indigobirds, as these might trace ancient speciation events. In some lizards, the remote relationships between species that later hybridized to form parthenogens are reflected in mitochondrial markers of distant past speciation and differentiation that are carried by the parthenogens (Moritz et al. 1992). However, within the indigobirds all mitochondrial haplotypes were very similar in restriction site profiles and none involved genetic distances comparable to those observed between the host species, as would be expected if there were survivors of past ancient cospeciations with host species. This suggests that none of the current parasite lineages of indigo- 
birds diverged as long ago as did the host species. Although the occurrence of host switches may provide an opportunity for introgression of mtDNA across species boundaries, the lack of any genetic divergence greater than $1 \%$ between indigobird haplotypes suggests this phenomenon is not masking ancient splitting events that would have occurred under a model of cospeciation with hosts.

The cospeciation and subsequent hybridization hypothesis might also be supported if there were morphological intermediates due to hybridization and introgression between the species. Morphologically intermediate males are quite uncommon (Payne et al. 1992, 1993; Payne and Payne 1994). No hybridization is apparent in size, plumage, or colors of the individual indigobirds used in the molecular samples, or in larger samples of museum specimens from the same regions (Payne et al. 1992, 1993).

Genetic distance comparisons assume similar rates of mutational change, but rates may vary among lineages (Gillespie 1991; Martin and Palumbi 1993; Hafner et al. 1994; Mindell et al. 1996). An assumption of similar rates is appropriate in the brood-parasitic finches and their host species, because in addition to being closely related (Bentz 1979; Sibley and Ahlquist 1990), Vidua and their estrildid hosts are similar in body size $(10-20 \mathrm{~g})$ and generation time (females breed at one year of age) (M.-Y. Morel 1973; Payne 1973a). Genetic distances between species of Vidua other than those within the paradise whydah and indigobird species complexes are comparable to distances between the estrildid finch species (2-4\%). This similarity suggests similar rates of molecular evolution in these two clades, rather than a slowdown of rate within the Vidua finches. Some variation is expected in the rate of molecular change in different clades, but the number of nucleotide substitutions between a pair of species should be positively correlated with time since divergence (Wilson et al. 1977; Nei 1987; Avise 1994). For these reasons, the much smaller genetic distances between species of brood parasites than between their hosts is consistent with a model of early speciation of the hosts and later colonization and differentiation of the parasites.

Parallel evolution (homoplasy of restriction gains/losses) could also explain why morphologically and behaviorally distinct parasite species were not distinguished in the molecular genetic results. Similarities between species that share identical haplotypes could be due to independent gains and losses of the same set of restriction sites. An independent evolution of identical restriction site profiles is unlikely, due to low rates of mutation, although this can be difficult to track with phylogenetic methodology. The statistically significant increase (nearly 50\%) in the number of steps required to describe a monophyletic origin of the haplotypes within each species argues against a model of parallel evolution of restriction sites.

Both molecular genetic evidence and morphological and behavioral comparisons suggest that the brood parasites have colonized their host species well after the host species had diverged, rather than having cospeciated with them. This has profound implications for our understanding of the ecological and evolutionary contexts of host-brood parasite associations and of the relative rapidity with which some morphological changes (e.g., mimicry of nestling mouth patterns) can take place.

\section{ACKNOWLEDGMENTS}

For help in the field we thank L. L. Payne, K. Hustler, and M. E. D. Nhlane. For permits in Zimbabwe we thank the National Museum of Natural History and the Chief Wildlife Officer, Department of National Parks and Wildlife. For permits in Malawi we thank the National Research Council of Malawi; the Chief Wildlife Officer, Department of Wildlife and National Parks; and the Officer in Charge, Lengwe National Park. The Museums of Malawi provided transport and assistance. For permits in Cameroon we thank the Government of the Republic of Cameroon, IRZ Institute for Zoological Research, and the Ministry of Tourism. NKK carried out the laboratory work in the University of Michigan Museum of Zoology, where W. M. Brown made available the facilities of the Laboratory of Molecular Systematics. D. L. Swofford allowed use of PAUP $4.0 \mathrm{~d} 49$ before its release, D. P. Mindell provided computer facilities and programs, and M. D. Sorenson advised on the analyses. The original recordings of songs by RBP and the specimens are in UMMZ. We thank the curators at AMNH, FMNH, USNM, BM(NH), and NMNH for access to their museum collections. For comments on the manuscript we thank J. L. Cracraft, D. P. Mindell, W. S. Moore, R. F. Rockwell, M. D. Sorenson, R. M. Zink, and two anonymous reviewers. Research was supported by the National Science Foundation (BSR 89-14890 and IBN-9412399).

\section{Literature Cited}

AquAdRo, C. F., AND B. D. GREENBERG. 1983. Human mitochondrial DNA variation and evolution: analysis of nucleotide sequences from seven individuals. Genetics 103:287-312.

AviSE, J. C. 1994. Molecular markers, natural history and evolution. Chapman and Hall, New York.

Avise, J. C., C. D. ANKNEY, AND W. S. Nelson. 1990. Mitochondrial gene trees and the evolutionary relationship of mallard and black ducks. Evolution 44:1109-1119.

BENTZ, G. D. 1979. The appendicular myology and phylogenetic relationships of the Ploceidae and Estrildidae (Aves: Passeriformes). Bull. Carnegie Mus. Nat. Hist. 15:1-25.

BRower, A. V. Z. 1996. Parallel race formation and the evolution of mimicry in Heliconius butterflies: a phylogenetic hypothesis from mitochondrial DNA sequences. Evolution 50:195-221.

Brown, W. M. 1980. Polymorphism in mitochondrial DNA of humans as revealed by restriction endonuclease analysis. Proc. Nat. Acad. Sci. USA 77:3605-3609.

1985. The mitochondrial genome of animals. Pp. 95-130 in R. J. MacIntyre, ed. Molecular evolutionary genetics. Plenum, New York.

BRown, W. M., AND J. Vinograd. 1974. Restriction endonuclease cleavage maps of animal mitochondrial DNAs. Proc. Nat. Acad. Sci. USA 71:4617-4621.

CARr, S. M., A. J. Brothers, AND A. C. Wilson. 1987. Evolutionary inferences from restriction maps of mitochondrial DNA from nine taxa of Xenopus frogs. Evolution 41:176-190.

Davies, N. B., A. F. G. Bourke, AND M. DE L. Brooke. 1989. Cuckoos and parasitic ants: interspecific brood parasitism as an evolutionary arms race. Trends Ecol. Evol. 4:274-278.

Desjardins, P., AND R. MORAIS. 1990. Sequence and gene organization of the chicken mitochondrial genome: a novel gene order in higher vertebrates. J. Mol. Biol. 212:599-634.

Dowling, T. E., C. Moritz, AND J. D. Palmer. 1990. Nucleic acids. II. Restriction site analysis. Pp. 250-317 in D. M. Hillis and C. Moritz, eds. Molecular systematics. Sinauer, Sunderland, MA.

Dowling, T. E., C. Moritz, J. D. Palmer, and L. H. Rieseberg. 1996. Nucleic acids. III. analysis of fragments and restriction sites. Pp. 249-320 in D. M. Hillis, C. Moritz, and B. K. Mable, eds. Molecular systematics. $2 d$ ed. Sinauer, Sunderland, MA. 
Edwards, S. V., AND A. C. Wilson. 1990. Phylogenetically informative length polymorphism and sequence variability in mitochondrial DNA of Australian songbirds (Pomatostomus). Genetics 126:695-711.

FriedmanN, H. 1960. The parasitic weaverbirds. U.S. Nat. Mus. Bull. 223:1-196.

Funk, D. J., D. J. Futuyma, G. Ortí, And A. Meyer. 1995. A history of host associations and evolutionary diversification for Ophraella (Coleoptera: Chrysomelidae): new evidence from mitochondrial DNA. Evolution 49:1008-1017.

GILL, F. B. 1994. Ornithology. 2d ed. W. H. Freeman, New York.

GILLESPIE, J. H. 1991. The causes of molecular evolution. Oxford Univ. Press, New York.

GolDING, B. 1992. The prospects for polymorphisms shared between species. Heredity 68:263-276.

Goodwin, D. 1960. Observations on avadavats and golden-breasted waxbills. Avic. Mag. 66:174-199.

. 1982. Estrildid finches of the world. Cornell Univ. Press, Ithaca, NY.

Hafner, M. S., P. D. Sudman, F. X. Villablanca, T. A. Spradling, J. W. Demastes, and S. A. Nadler. 1994. Disparate rates of molecular evolution in cospeciating hosts and parasites. Science 265:1087-1090.

HiguChI, H., AND S. SATo. 1984. An example of character release in host selection and egg colour of cuckoos Cuculus sp. in Japan. Ibis 126:398-404.

Hilborn, R., and M. MAngel. 1997. The ecological detective. Monographs in population biology no. 28. Princeton Univ. Press, Princeton, NJ.

Hixson, J. E., AND W. M. Brown. 1986. A comparison of small ribosomal RNA genes from the mitochondrial DNA of the great apes and humans: sequence, structure, evolution, and phylogenetic implications. Mol. Biol. Evol. 3:1-18.

ImmelmanN, K., A. Piltz, ANd R. Sossinka. 1977. Experimentelle Untersuchungen zur Bedeutung der Rachenzeichnungen junger Zebrafinken. Z. Tierpsychol. 45:210-218.

JOHNSON, N. K., AND C. CICERO. 1991. Mitochondrial DNA sequence variability in two species of sparrows of the genus Amphispiza. Pp. 600-610 in Acta XX Congressus Internationalis Ornithologici, Christchurch, New Zealand.

KaKIZAWA, R., AND M. WATADA. 1985. The evolutionary genetics of the Estrildidae. J. Yamashina Inst. Ornithol. 17:143-158.

Kessler, L. G., AND J. C. Avise. 1984. Systematic relationships among waterfowl (Anatidae) inferred from restriction endonuclease analysis of mitochondrial DNA. Syst. Zool. 33:370-380.

KLEIN, N. K., AND W. M. BROWN. 1994. Intraspecific molecular phylogeny in the yellow warbler (Dendroica petechia), and implications for avian biogeography in the West Indies. Evolution 48:1914-1932.

Klein, N. K., R. B. Payne, and M. E. D. Nhlane. 1993. A molecular perspective on speciation in the brood parasitic Vidua finches. Pp. 29-39 in R. T. Wilson, ed. Proceedings of the VIII pan-African ornithological congress, Bujumbura.

Lansman, R. A., R. O. Shade, J. F. Shapira, and J. C. Avise. 1981. The use of restriction endonucleases to measure mitochondrial DNA sequence relatedness in natural populations. J. Mol. Evol. 17:214-226.

Martin, A. P., And S. R. Palumbi. 1993. Body size, metabolic rate, generation time, and the molecular clock. Proc. Nat. Acad. Sci. USA 900:4087-4091.

Mindell, D. P., A. KNight, C. Baer, And C. J. Huddleston. 1996. Slow rates of molecular evolution in birds and the metabolic rate and body temperature hypotheses. Mol. Biol. Evol. 13:422-426.

MitTer, C., AND D. R. Brooks. 1983. Phylogenetic aspects of coevolution. Pp. 65-98 in D. J. Futuyma and M. Slatkin, eds. Coevolution. Sinauer, Sunderland, MA.

MOORE, J., AND N. J. GoTELLI. 1996. Evolutionary patterns of altered behavior and susceptibility in parasitized hosts. Evolution 50:807819.

MoORE, W. S. 1995. Inferring phylogenies from mtDNA variation: mitochondrial gene-trees versus nuclear-gene trees. Evolution 49: 718-726.

MorAN, P., AND I. KORNFIELD. 1993. Retention of an ancestral poly- morphism in the mbuna species flock (Teleostei: Cichlidae) of Lake Malawi. Mol. Biol. Evol. 10:1015-1029.

MOREL, G. R. 1959. Le parasitisme de Lagonosticta senegala (L.) par Hypochera chalybeata (Müller). Pp. 157-159 in M. K. Rowan, ed. Proceedings of the I pan-African ornithological congress, Livingstone.

MoREL, M.-Y. 1973. Contribution à l'étude dynamique de la population de Lagonosticta senegala L. (Estrildides) à Richard-Toll (Sénégal). Interrelations avec le parasite Hypochera chalybeata (Müller) (Viduines). Mémoires Museum National d'Histoire $\mathrm{Na}$ turelle, serie A, Zoologie 78.

Moritz, C., T. E. Dowling, AND W. M. Brown. 1987. Evolution of animal mitochondrial DNA: relevance for population biology and systematics. Annu. Rev. Ecol. Syst. 18:269-292.

MorITZ, C., J. W. Wright, AND W. M. Brown. 1992. Mitochondrial DNA analyses and the origin and relative age of parthenogenetic Cnemidophorus: phylogenetic constraints on hybrid origins. Evolution 46:184-192.

NEI, M. 1987. Molecular evolutionary genetics. Columbia Univ. Press, New York.

NEl, M., AND F. TAJimA. 1983. Maximum likelihood estimation of the number of nucleotide substitutions from restriction site data. Genetics 105:207-217.

Nicolal, J. 1964. Der Brutparasitismus der Viduinae als ethologisches Problem. Z. Tierpsychol. 21:129-204.

- 1973. Das Lernprogramm in der Gesangsausbildung der Strohwitwe Tetraenura fischeri Reichenow. Z. Tierpsychol. 32: 113-138.

__. 1974. Mimicry in parasitic birds. Sci. Am. 231:92-98.

PAGE, R. D. M. 1994. Parallel phylogenies: reconstructing the history of host-parasite assemblages. Cladistics 10:155-173.

PAYNE, R. B. 1973a. Behavior, mimetic songs and song dialects, and relationships of the parasitic indigobirds (Vidua) of Africa. Ornithological Monographs, no. 11. American Ornithologists' Union, Washington, DC.

- $1973 \mathrm{~b}$. Vocal mimicry of the paradise whydahs (Vidua) and response of female whydahs to the songs of their hosts (Pytilia) and their mimics. Anim. Behav. 21:762-771.

. 1977a. The ecology of brood parasitism in birds. Annu. Rev. Ecol. Syst. 8:1-28.

. 1977b. Clutch size, egg size, and the consequences of single vs. multiple parasitism in parasitic finches. Ecology 58:500-513.

1982. Species limits in the indigobirds (Ploceidae, Vidua) of West Africa: mouth mimicry, song mimicry, and description of new species. Miscellaneous publications of the University of Michigan Museum of Zoology, no. 162, Ann Arbor.

- 1985a. Behavioral continuity and change in local song populations of village indigobirds, Vidua chalybeata. Z. Tierpsychol. 70:1-44.

- 1 1985b. Song populations and dispersal in steelblue and purple widowfinches. Ostrich 56:135-146.

. 1990. Song mimicry by the village indigobird (Vidua chalybeata) of the red-billed firefinch (Lagonosticta senegala). Vogelwarte 35:321-328.

. 1991. Female and first-year male plumages of paradise whydahs Vidua interjecta. Bull. Br. Ornithol. Club 111:95-100.

. 1997. Avian brood parasitism. Pp. 338-369 in D. H. Clayton and J. Moore, eds. Host-parasite evolution. Oxford Univ. Press, Oxford.

- 1998. Brood parasitism in birds: strangers in the nest. Bioscience $48: 377-386$.

- In press. A new species of firefinch Lagonosticta from northern Nigeria, and its association with the Jos Plateau indigobird Vidua maryae. Ibis 140.

PAYNe, R. B., AND L. L. PAYNe. 1994. Song mimicry and species status of the indigobirds Vidua: associations with quail-finch $O r$ tygospiza atricollis, goldbreast Amandava subflava and brown twinspot Clytospiza monteiri. Ibis 136:291-304.

1995. Song mimicry and association of brood-parasitic indigobirds (Vidua) with Dybowski's twinspot (Euschistospiza dybowskii). Auk 112:649-658.

Payne, R. B., L. L. Payne, and M. E. D. Nhlane. 1992. Song 
mimicry and species status of the green widowfinch Vidua codringtoni. Ostrich 63:86-97.

Payne, R. B., L. L. Payne, M. E. D. Nhlane, and K. Hustler 1993. Species status and distribution of the parasitic indigo-birds Vidua in east and southern Africa. Pp. 40-52 in R. T. Wilson, ed. Proceedings of the VIII pan-African ornithological congress, $\mathrm{Bu}$ jumbura.

Payne, R. B., L. L. PAyne, AND J. L. Woods. In press. Song learning in brood parasitic indigobirds Vidua chalybeata: song mimicry of the host species. Anim. Behav. 55.

Platt, J. R. 1964. Strong inference. Science 146:347-353.

Plowright, R., AND R. E. OWen. 1980. The evolutionary significance of bumble bee color patterns: a mimetic interpretation. Evolution 34:622-637.

RADTKEY, R. R., AND M. C. Singer. 1995. Repeated reversals of host preference evolution in a specialist insect herbivore. Evolution 49:351-359.

ReED, H. J., AND N. H. FreEman. 1991. Does an absence of gape markings affect survival of leucistic young in the zebra finch? Bird Behav. 9:58-63.

Richman, A. D., AND T. PRice. 1992. Evolution of ecological differences in the Old World leaf warblers. Nature 355:817-821.

RoNQUIST, F. 1994. Evolution of parasitism among closely related species: phylogenetic relationships and the origin of inquilinism in gall wasps (Hymenoptera, Cynipidae). Evolution 48:241-266.

ROTHSTEIN, S. I. 1990. A model system for coevolution: avian brood parasitism. Annu. Rev. Ecol. Syst. 2:481-508.

Seutin, G., B. N. White, AND P. T. BoAg. 1991. Preservation of avian blood and tissue samples for DNA analyses. Can. J. Zool. 69:82-90.

Seutin, G., N. K. Klein, R. E. Ricklefs, and E. Bermingham. 1994. Historical biogeography of the bananaquit (Coereba flaveola) in the Caribbean region: a mitochondrial DNA assessment. Evolution 48:1041-1061.

Seutin, G., L. M. Ratcliffe, and P. T. Boag. 1995. Mitochondrial DNA homogeneity in the phenotypically diverse redpoll finch complex (Aves: Carduelinae: Carduelis flammea-hornemanni). Evolution 49:962-973.

ShIELDS, G. F., AND K. M. HeLM-ByChowsKI. 1988. Mitochondrial DNA of birds. Curr. Ornithol. 5:273-195.

Sibley, C. G., AND J. E. Ahlquist. 1990. Phylogeny and classification of birds: a study in molecular evolution. Yale Univ. Press, New Haven, CT.

Singer, M. C., D. NG, D. VASCo, AND C. D. Thomas. 1992. Rapidly evolving associations among oviposition preferences fail to constrain evolution of insect diet. Am. Nat. 139:9-20.

SKAGEN, S. K. 1988. Asynchronous hatching and food limitation: a test of Lack's hypothesis. Auk 105:78-88.

SKEAD, C. J. 1957. Parasitism of the common waxbill, Estrilda astrild, by the pin-tailed widow-bird, Vidua macroura. Ostrich 28: 214-216.

SKEAD, D. M. 1975. Ecological studies of four estrildines in the central Transvaal. Ostrich Suppl. 11:1-55.

Smith, E. F. G., P. ARCTANDER, J. FJeldSȦ, AND O. G. Amir. 1991. A new species of shrike (Laniidae: Laniarius) from Somalia, verified by DNA sequence data from the only known individual. Ibis 133:227-235.

SMITH, G. R. 1992. Introgression in fishes: significance for paleontology, cladistics, and evolutionary rates. Syst. Biol. 41:41-57.

Southern, H. N. 1954. Mimicry in cuckoos' eggs. Pp. 257-270 in J. Huxley, A. C. Hardy, and E. B. Ford, eds. Evolution as a process. Collier, New York.

SWOFFORD, D. L. 1993. PAUP: phylogenetic analysis using parsimony. Vers. 3.1. Illinois Natural History Survey, Champaign.

TAJIMA, F. 1983. Evolutionary relationship of DNA sequences in finite populations. Genetics 105:437-460.

Templeton, A. R. 1983. Phylogenetic inference from restriction endonuclease cleavage site maps with particular reference to the evolution of humans and the apes. Evolution 37:221-244.

VAWTER, L., AND W. M. BROWN. 1986. Nuclear and mitochondrial DNA comparisons reveal extreme rate variation in the molecular clock. Science 234:194-196.
Wilson, A. C., S. S. Carlson, and T. J. White. 1977. Biochemical evolution. Annu. Rev. Biochem. 46:573-639.

WOLTERS, H. E. 1987. Zur Stammesgeschichte der afrikanischen Prachtfinken. Trochilus 8:37-76.

Zink, R. M., D. L. Dittmann, and W. L. Rootes. 1991. Mitochondrial DNA variation and the phylogeny of Zonotrichia. Auk 108:578-584.

Corresponding Editor: R. Zink

\section{APPENDIX 1}

Species and geographic sources of specimens used in the mitochondrial DNA analyses, and haplotype identities for each specimen. Haplotype numbers for indigobirds are in boldface, whether unique or shared with another bird.

\section{Vidua: Indigobirds}

Vidua camerunensis, $n=10$, mimics of $L$. rubricata, Cameroon: Tibati, A194 (\#A194), A217 (\#A217), A225 (\#A210), A244

(\#A217); Wakwa, A138 (\#A138); mimics of C. monteiri, Cameroon: Tibati, A203 (\#A210), A210 (\#A210), A215 (\#A194), A229 (\#A229), A230 (\#A230) independent juvenile male at call-site of males A203, A210, and A229, no song.

V. codringtoni, $n=4$, Zimbabwe: Premier Estate, A07 (\#A07), A14 (\#A14), A08 (\#A31) song mimic of L. rubricata; Malawi: Lengwe NP, A33 (\#A33).

V. funerea nigerrima, $n=4$, Zimbabwe: Chipinge, A18 (\#A31); Jersey Tea Estate, A15 (\#A31); Malawi: Chididi, A100 (\#A100); Pwezi, A71 (\#A71).

V. larvaticola, $n=1$, Cameroon: Garoua, A164 (\#A164).

V. nigeriae, $n=2$, Cameroon: Garoua, A170 (\#A170), A173 (\#A173).

V. purpurascens, $n=9$, Zimbabwe: Beatrice, A01 (\#A01); Eiffel Blue, A02 (\#A30); Jabulisa, A22 (\#A31); Kadoma, A04 (\#A03); Malawi: Khondowe, A72 (\#A72); Lengwe NP, A30 (\#A30); Mwezisi, A73 (\#A31); Rumphi, A67 (\#A67); Tomali, A62 (\#A03).

V. raricola, $n=5$, Cameroon: Ngaoundere, A130 (\#A210), A161 (\#A 170), A200 (\#A170); Tibati, A202 (\#A202), A234 (\#A234).

V. wilsoni, $n=2$, Cameroon: Ngaoundere, A139 (\#A173), Tchéboa, A186 (\#A186).

V. chalybeata amauropteryx, $n=5$, Zimbabwe: Eiffel Blue, A03

(\#A03); Gwaai River, A21 (\#A03); Malawi: Lengwe, A31

(\#A31); Limbe, A115 (\#A33) song mimic of L. rubricata;

Mwezisi, A88 (\#A88).

V. chalybeata neumanni, $n=3$, Cameroon: Garoua, A177

(\#A177), A179 (\#A179), A189 (\#A189).

Vidua: Paradise Whydahs

Vidua paradisaea, $n=2$, Malawi: Rumphi, A81 (\#A81); captive ex Tanzania, 025 (\#025).

V. obtusa, $n=2$, Malawi: Rumphi, A82 (\#A82), A87 (\#A87).

V. interjecta, $n=2$, captive, o511 (\#0511) female, o5 12 (\#0511) male.

V. orientalis aucupum, $n=2$, captive, 053 (\#053), o561 (\#0561).

\section{Vidua: Other Whydahs}

Vidua macroura, $n=4$, Cameroon: Ngaoundere, A147 (\#o19);

Malawi, Mwezisi, A89 (\#018); captive, o18 (\#018), o19(\#019). $V$. hypocherina, $n=2$, captive, 031 (\#031), o32 (\#o31).

$V$. fischeri, $n=2$, captive, o50 (\#050), 062 (\#062).

V. regia, $n=2$, captive, o38 (\#038), 039 (\#038).

\section{Estrildidae Finches}

Amadina fasciata, $n=2$, captive, 081 (\#081), 0422 (\#081).

Clytospiza monteiri, $n=1$, Cameroon: Ngaoundere, A132 (\#A132).

Hypargos niveoguttatus, $n=2$, Zimbabwe: Gwaai River, A24 (\#A24); captive, 099 (\#099).

Lagonosticta larvata, $n=1$, Cameroon: Ngaoundere, A145 (\#A 145). 
L. rara rara, $n=1$, Cameroon: Tibati, A248 (\#A248).

$L$. rara forbesi, $n=1$, captive, o36 (\#036).

L. rhodopareia, $n=5$, Zimbabwe: Jabulisa, A23 (\#A23); Malawi: Lengwe NP, A41 (\#A41), A42 (\#A41), A43 (\#A41); captive, \#A107 (\#A23).

L. rubricata haematocephala, $n=2$, Malawi: Limbe, A114 (\#A114), Mwezisi, A75 (\#A75).

L. r. congica, $n=1$, Cameroon: Ngaoundere, A131 (\#A131).

L. $r$. poliocephala, $n=1$, captive, 013 (\#o13).

L. rufopicta, $n=1$, captive, \#030 (\#030).

L. senegala rendalli, $n=3$, Malawi: Mwezisi, A74 (\#A74), Lengwe NP, A56 (\#A56), A104 (\#A104).

L. s. rhodopsis, $n=2$, Cameroon: Garoua, A167 (\#A167), A171 (\#A171).

Mandingoa nitidula, $n=1$, Malawi: Limbe, A113 (\#A113).

Pytilia afra, $n=3$, Malawi: Lengwe NP, A46 (\#A46), A51 (\#A46); captive, o107 (\#A46)

P. hypogrammica, $n=2$, captive, o108 (\#o108), 098 (\#0108).

P. melba grotei, $n=3$, Malawi: Lengwe NP, A35 (\#A35), A36 (\#A35), A57 (\#A57).

$P$. m. percivali, $n=2$, captive, o56 (\#056), 0510 (\#056).

$P$. $m$. citerior, $n=2$, captive, o06 (\#o06), 052 (\#o52).

P. phoenicoptera, $n=2$, captive, o54 (\#061), o61 (\#061).

\section{APPENDIX 2}

Restriction site map positions for all taxa and haplotypes used in this study. Map position is in kilobase pairs from the conserved ClaI site. Enzyme abbreviations are: $A p=A p a \mathrm{I}, B a=B a m H \mathrm{I}, B c$ $=B c l \mathrm{I}, B g=B g l \mathrm{II}, B s=B s t E \mathrm{II}, C l=C l a \mathrm{I}, D r=D r a \mathrm{I}, E a=$ EagI, Ec $=$ EcoRI, $H i=H i n d I I I, K p=K p n I, N c=N c o I, N d=$ NdeI, $N h=$ NheI, $P v=P v u I I, S a=S a l I, S c=S a c I I, X b=X b a I$. The letters after the enzyme abbreviations refer to the particular restriction site. Where more than one map position is listed for a site, the exact position could not be determined due to a lack of intervening sites for comparison. The map is presented in the direction depicted by the chicken gene map (Desjardins and Morais 1990), rather than the direction of the chicken sequence.

$\begin{array}{llllll}C l \mathrm{~A} & 0.0 & H i \mathrm{I} & 6.7 & N h \mathrm{G} & 11.6 \\ A p \mathrm{D} & 0.15 & B s \mathrm{~A} & 6.75 & B c \mathrm{~L} & 11.7 \\ B g \mathrm{~A} & 0.195 & B c \mathrm{Q} & 6.78 & S a \mathrm{~B} & 11.8 \\ K p \mathrm{~F} & 0.30 & B c \mathrm{~B} & 6.83 & N h \mathrm{~K} & 11.9 \\ S c^{*} & 0.32 & N h \mathrm{O} & 6.9 & H i \mathrm{G} & 11.95 \\ E a \mathrm{~B} & 0.6 & B c \mathrm{~F} & 7.14 & K p \mathrm{D} & 12.0 \\ D r \mathrm{E} & 0.7 & B c \mathrm{~V} & 7.15 & A p \mathrm{~F} & 12.05 \\ B c \mathrm{G} & 0.73 & C l \mathrm{H} & 7.4 & B c \mathrm{R} & 12.1 \\ E a \mathrm{E} & 0.8 & X b \mathrm{H} & 7.5 & H i \mathrm{M} & 12.1 \\ D r \mathrm{~B} & 0.9 & N d \mathrm{~F} & 7.55 & C l \mathrm{~F} & 12.2 \\ N d \mathrm{U} & 1.05 & H i \mathrm{~B} & 7.65 & H i \mathrm{~K} & 12.35 \\ E c \mathrm{E} & 1.05 & N d \mathrm{P} & 7.67 & B c \mathrm{~T} & 12.4 \\ N d \mathrm{C} & 1.2 & N c \mathrm{~K} & 7.69 & X b \mathrm{I} & 12.4 \\ B a \mathrm{~A} & 1.3 & X b \mathrm{D} & 7.72 & B c \mathrm{M} & 12.6 \\ N d \mathrm{~J} & 1.5 & B c \mathrm{P} & 7.83 & N h \mathrm{D} & 12.9 \\ E c \mathrm{~B} & 1.6 & D r \mathrm{D} & 7.9 & N c \mathrm{E} & 13.05 \\ K p \mathrm{~A} & 1.65 & B a \mathrm{G} & 7.95 & N h \mathrm{I} & 13.1 \\ E a \mathrm{~F} & 1.7 & N d \mathrm{~A} & 8.0 & P v \mathrm{H} & 13.12 \\ K p \mathrm{H} & 1.75 & N h \mathrm{H} & 8.1 & P v \mathrm{~F} & 13.4 \\ N d \mathrm{~B} & 1.85 & B a \mathrm{E} & 8.16 & X b \mathrm{~F} & 13.5\end{array}$

APPENDIX 2. Continued.

\begin{tabular}{|c|c|c|c|c|c|}
\hline$B g \mathrm{D}$ & 1.92 & DrM & 8.2 & $A p \mathrm{E}$ & 13.5 \\
\hline$B g \mathrm{E}$ & 1.97 & $N c \mathrm{M}$ & 8.2 & $K p \mathrm{~B}$ & 13.62 \\
\hline$E c \mathrm{~N}$ & 2.0 & $B c S$ & 8.3 & $A p \mathrm{~B}$ & 13.7 \\
\hline$A p \mathrm{H}$ & 2.0 & $\mathrm{BaB}$ & 8.4 & $P v \mathrm{Y}^{* *}$ & $13.77 / 13.2$ \\
\hline$N d \mathrm{~V}$ & 2.05 & $H i \mathrm{H}$ & 8.6 & $P v \mathrm{~N}$ & 13.8 \\
\hline$E c X Y$ & 2.05 & $P v \mathrm{AA}$ & 8.75 & $P v \mathrm{Z}$ & 13.9 \\
\hline$N d \mathrm{~W}$ & $2.1 / 2.8$ & $B s \mathrm{G}$ & 8.8 & $E c \mathrm{~A}$ & 14.0 \\
\hline$N h \mathrm{~N}$ & 2.2 & $E a \mathrm{D}$ & 8.85 & $B a C$ & 14.1 \\
\hline$B a \mathrm{D}$ & 2.25 & $P v \mathrm{~S}$ & 8.85 & NhM & 14.15 \\
\hline$E a \mathrm{~K}$ & $2.4 / 1.0$ & $X b \mathrm{E}$ & 8.85 & $P v \mathrm{E}$ & 14.2 \\
\hline $\mathrm{DrC}$ & 2.45 & $N d \mathbf{H}$ & 8.9 & $B g C$ & 14.3 \\
\hline$E a I$ & 2.6 & $D r \mathrm{P}$ & $8.96 / 10.4$ & $B s C$ & 14.35 \\
\hline$X b \mathrm{C}$ & 2.68 & $\mathrm{HiC}$ & 9.0 & $N d \mathrm{D}$ & 14.45 \\
\hline$P v \mathrm{~K}$ & 2.7 & $K p \mathrm{C}$ & 9.03 & $B c \mathrm{C}$ & 14.48 \\
\hline$E a \mathrm{~J}$ & 2.8 & Bs $\mathrm{B}$ & 9.2 & $A p \mathrm{G}$ & 14.5 \\
\hline$N h \mathrm{C}$ & 2.88 & $B a \mathrm{P}$ & $9.2 / 12.05$ & $N h \mathrm{~J}$ & 14.51 \\
\hline$C l \mathrm{D}$ & 2.9 & $X b \mathrm{~K}$ & 9.3 & $B a \mathbf{J}$ & 14.55 \\
\hline$B a \mathrm{M}$ & 3.05 & $N c \mathrm{~F}$ & 9.3 & NhE & 14.6 \\
\hline$E c \mathrm{~F}$ & 3.23 & $A p \mathrm{~J}$ & 9.35 & $N c \mathrm{G}$ & 14.7 \\
\hline$P v Q$ & 3.3 & $P v L$ & 9.4 & ApL & $14.75 / 14.9$ \\
\hline$E a C$ & 3.6 & $C / \mathrm{B}$ & 9.5 & $B c \mathrm{I}$ & 14.8 \\
\hline$N d \mathrm{E}$ & 3.7 & $N c \mathrm{C}$ & 9.55 & NhA & 14.9 \\
\hline$N d \mathrm{Q}$ & 3.72 & $\mathrm{BaO}$ & 9.6 & $D r \mathrm{H}$ & 15.0 \\
\hline $\mathrm{ClC}$ & 3.75 & $H i \mathrm{E}$ & 9.65 & $X b \mathbf{J}$ & 15.1 \\
\hline$N h \mathrm{~B}$ & 3.8 & $H i \mathrm{~L}$ & 9.7 & $P \nu \mathrm{W}$ & 15.1 \\
\hline$S a \mathrm{E}$ & 3.9 & $E c \mathrm{~L}$ & 9.7 & $B c A$ & 15.25 \\
\hline$B C J$ & 4.0 & $B c \mathrm{D}$ & 9.75 & $X b \mathrm{~B}$ & 15.3 \\
\hline$E_{c} \mathrm{H}$ & 4.4 & $B a I$ & 9.8 & DrK & 15.5 \\
\hline$H i \mathrm{~F}$ & 4.5 & $A p \mathrm{~K}$ & 9.82 & $E a A$ & 15.55 \\
\hline$D r G$ & 4.6 & $\mathrm{SaC}$ & 10.0 & $S c^{* * *}$ & 15.6 \\
\hline$B a \mathrm{~L}$ & 4.7 & $B g B$ & 10.1 & $K p \mathrm{E}$ & 15.7 \\
\hline$N d \mathbf{K}$ & 4.8 & $E a \mathrm{G}$ & 10.15 & $\mathrm{HiA}$ & 15.8 \\
\hline$A p \mathbf{I}$ & 4.85 & $B a \mathrm{~K}$ & 10.2 & $A p \mathrm{~A}$ & 15.95 \\
\hline $\mathrm{NcH}$ & 4.9 & $N h \mathrm{~L}$ & 10.2 & DrA & 16.0 \\
\hline$P v C$ & 5.0 & $B c \mathrm{~N}$ & 10.25 & $\operatorname{DrN}$ & 16.2 \\
\hline$N d \mathrm{~L}$ & 5.2 & $S a \mathrm{~A}$ & 10.3 & $P \nu \mathrm{G}$ & 16.6 \\
\hline$P v \mathrm{D}$ & 5.25 & $E c \mathrm{C}$ & 10.3 & $X b A$ & 16.85 \\
\hline$E a \mathrm{H}$ & 5.3 & $P v \mathrm{~B}$ & 10.35 & $E c \mathrm{~J}$ & 16.95 \\
\hline$D r F$ & 5.6 & $N c B$ & 10.4 & $D r Q$ & $16.95 / 0.02$ \\
\hline$B c \mathrm{E}$ & 5.65 & $B s F$ & 10.4 & $P v D E$ & $?$ \\
\hline $\mathrm{HiJ}$ & 5.7 & $N c I$ & 10.43 & $P v \mathrm{DF}$ & $?$ \\
\hline$E a X$ & $5.7 / 13.4$ & $E c \mathrm{P}$ & 10.6 & $P v \mathrm{DG}$ & ? \\
\hline$N d \mathrm{G}$ & 5.95 & $P v \mathrm{~J}$ & 10.8 & & \\
\hline $\mathrm{ClE}$ & 6.0 & $E c \mathrm{G}$ & 10.85 & & \\
\hline$D r \bar{L}$ & 6.05 & $N d \mathbf{I}$ & 10.9 & & \\
\hline$B c \mathrm{H}$ & 6.17 & $H i \mathrm{D}$ & 10.92 & & \\
\hline$N h \mathrm{~F}$ & 6.2 & $N c \mathrm{~A}$ & 11.1 & & \\
\hline$E c \mathbf{K}$ & 6.3 & PvA & 11.2 & & \\
\hline$N c \mathrm{D}$ & 6.5 & $N d \mathrm{BB}$ & 11.4 & & \\
\hline$B a \mathrm{~F}$ & 6.7 & $B s \mathrm{E}$ & 11.5 & & \\
\hline
\end{tabular}

* The SacII site, conserved in vertebrates, in the 12S rRNA gene. ** PvuIIY and $P v u I I N$ could be the same site.

*** The SacII site, conserved in vertebrates, in the 16s rRNA gene.

These two SacII sites were used only as reference points for aligning restriction site maps. They were not included in the phylogenetic analysis, nor in estimates of sequence divergence. 


\section{APPENDIX 3}

Presence (1) and absence ( 0 ) of 200 restriction sites in estrildid and Vidua finches. Numbers next to species names indicate the haplotype numbers; some were shared among individuals and (in the Vidua indigobirds) among species (cf. Table 1). Restriction enzymes are identified by standard abbreviations; for restriction site map positions on the mitochondrial DNA molecule, see Appendix 2.

ApaIA ApaIB ApaID ApaIE ApaIF ApaIG ApalH ApaII ApaIJ ApaIK ApaIL BamHIA BamHIB BamHIC BamHID BamHIE BamHIF BamHIG BamHII BamHIJ BamHIK BamHIL BamHIM BamHIO BamHIP BclIA BclIB BclIC BclID BclIE BclIF BclIG BclIH BclII BclIJ BcllL BclIM BclIN BclIP BclIQ BclIR BclIS BclIT BclIV BglIIA BglIIB BglIIC BgIIID BglIIE BstEIIA BstEIIB BstEIIC BstEIIE BstEIIF BstEIIG ClaIA ClaIB ClaIC ClaID ClaIE ClaIF ClaIH DraIA DraIB DraIC DraID DraIE DraIF DraIG DraIH DraIK DraIL DraIM DraIN DraIP DraIQ EagIA EagIB EagIC EagID EagIE EagIF EagIG EagIH EagII EagIJ EagIK EagIX EcoRIA EcoRIB EcoRIC EcoRIE EcoRIF EcoRIG EcoRIH EcoRIJ EcoRIK EcoRIL EcoRIN EcoRIP EcoRIXY HindIIIA HindIIIB HindIIIC HindIIID HindIIIE HindIIIF HindIIIG HindIIIH HindIIII HindIIIJ HindIIIK HindIIIL HindIIIM KpnIA KpnIB KpnIC KpnID KpnIE KpnIF KpnIH NcoIA NcoIB NcoIC NcoID NcoIE NcoIF NcoIG NcoIH NcoII NcoIK NcoIM NdeIA NdelB NdeIC NdeID NdeIE NdeIF NdeIG NdeIH NdeII NdeIJ NdeIK NdeIL NdeIP NdeIQ NdeIU NdeIV NdeIW NdeIBB NheIA NheEB NheIC NheID NheIE NheIF NheIG NheIH NheII NheIJ NheIK NheIL NheIM NheIN NheIO PvulIA PvuIIB PvuIIC PvuIID PvuIIE PvuIIF PvuIIG PvuIIH PvuIIJ PviIIK PvuIIL PvuIIN PvIIQ PvuIIS PvuIIW PvuIIY PvuIIZ PvuIIAA PvuIIDE PvuIIDF PvuIIDG SalIA SalIB SalIC SalIE XbaIA XbaB XbalC XbaID XbaIE XbaIF XbalH Xball XbalJ XbalK

Pytilia afra A46
P. melba grotei A35
P. melba grotei A57
P. melba percivali o56
P. melba citerior 006
P. melba citerior 052
P. phoenicoptera 061
P. hypogramica o108
Amadina fasciata 081
L. senegala A74
L. senegala A56
L. senegala A104
L. senegala A167
L. Senegala A171
L. rubricata A75
L. rubricata A114
L. rubricata A131
L. rubricata o13
L. rhodopareia A23
L. rhodopareia A41
L. rara o36
L. rara A248
L. larvata A145
L. rufopicta o30
Clyespira fonteiri A132

C1ytospiza monteiri A132

Hypargos niveogut tatus A24

H. niveoguttatus 099

Mandingoa nitidula A113

V. orientalis 053

v. orientalis 0561

V. paradisaed 025

V. paradisaea $A 81$

V. obtusa $\mathrm{AB?}$

V. obtusa $\mathrm{A} 82$

v. interjecta o511 11101000000000110000000001011001000100010000100000 v. regia 038

V. fischeri 062

V. fischeri 050

$V$. macroura 018

V. macroura 019

$v$. hypocherina 031

indigo $\mathrm{AO} 1$

indigo $\mathrm{AO} 3$

indigo $A 07$

indigo $\mathrm{Al} 4$

indigo $A 30$

indigo $A 31$

indigo $A 33$

indigo $A 67$

indigo $A 71$

indigo $A 72$

indigo $\mathrm{A} 88$

indigo $\mathrm{A} 100$

indigo $\mathrm{A} 138$

indigo A164

indigo $A 170$

indigo $\mathrm{A} 173$

indigo $\mathrm{A177}$

indigo $\mathrm{A} 179$

indigo $A 186$

indigo $\mathrm{A} 18 \mathrm{~g}$

indigo $\mathrm{A} 194$

indigo $\mathrm{A} 202$

indigo A210

indigo $\mathrm{A} 217$

indigo A229

indigo $A 230$

indigo $\mathrm{A} 234$

11000000000110000000000001111000000000000000110000 10100000000010111100000001111110000000000000101100 10100000000010111100000001111110000000000000101100 10100000000011111100000001111100000000000000100110

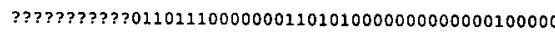
?????????:011011100000001101010000000000000100000 11000000000110000000000001111000000000000000100000 11000000000110000000000001111000000000000000100000 11100000000010100000000001111000001101000000100000 11110000000000000000000001001000000000000000100000 11100000100000010000000001001000000000000000100000 11100000100000010000000001001000000000000000100000 11100000100000010000000001001000000000000000100000

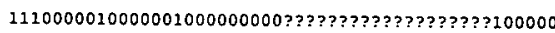
11101000110000110100000001101000010000000000100001 11101000110000110100000001101000010000000000100001 11101000110000110100000001111000010000000000100001 11101000110000110100000001111000010000000000100001 11101000000000110100000001101000010000000000100001 11101000000000110100000001101000010000000000100001 11100000000010110100000101010000000000000010100000 11100000000010010100000001010000000000000010100000

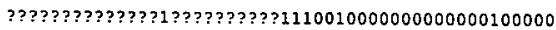
1110100000001110010000000101000000000000001010000 ?

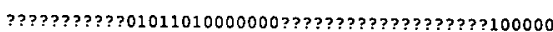

11100001000000110000001001110010000000000000100000 11100001000000110000000001110010000000000000100000 11110000000000100000000001111000000000000000100000 11101100000010101000100001011001000110010000100000 11101100000010101000100001011001000110010000100000 11101000000000110100000001011001000100010000100000 11101000000000110000000001011001000100010000100000 11101000000000110100000001011001000100010000100000 11101100000010101000100001011001000110010000100000

P. melba grotei A35
APPENDIX 3. Continued.

11100000100000101000010001011001100100111000100001 1110000100100010100101000101000110010011100010000 ? 1110000100100010100101000101000110010010100010000 ? 11100000100000010100000001011001000100110000100000 11100000100000011110000001001001000100110000100000 11100000000000000000000001011001100110110000110000 11100111000000100001000001011001100100111101100000 11001100000000100001000001011001100100111101100000 11100111000000100001000001011001100100111101100000 11100111000000100001000001011001100100111101100000 11100110000000100001000001011001100100111101100000 11100110000000100001000001011001100100111101100000 11100110000000100001000001011001100100111101100000 11100111000000100001000001011001100100111101100000 11100110000000100001000001011001100100111101100000 11100100000000100001000001011001100100111101100000 11100110000000100001000001011001100100111101100000 11100110000000100001000001011001100100111101100000 ??????????000101001010001011001100100111101100000 11100110000000101001010001011001100100111101100000 11100110000000101001010001011001100100111101100000 11100110000000101001010001011001100100111101100000 11100110000000101001000001011001100100111101100000 11100110000000101001000001011001100100111101100000

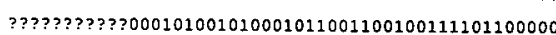
11100110000000100001000001011001100100111101100000 11001100000000101001010001011001100100111101100000 11100110000000101001010011011001100100111101100000 11100110000000101001010001011001100100111101100000 11100110000000101001010001011001100100111101100000

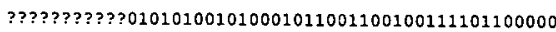
11001100000000101001010001011001100100111101100000 11100110000000101001010001011001100100111101100000
Pytilia afra A46

P. melba grotei $A 57$

P. melba percivali 056

P. melba citerior 005

P. melba citerior o52

P. phoenicoptera 061

P. hypogramica 0108

Amadina fasciata 081

L. senegala A74

L. senegala AS6

L. senegala A104

L. senegala A16?

L. Senegala A171

L. rubricaca $\mathrm{A} 75$

L. rubricata Alla

L. rubricata A131

L. rubricala 013

L. rhodopareia A23

L. rhodopareia $A 41$

L. rara 036

L. rara $A 248$

L. Larvata $A 145$

L. rufopicta 030

Clytospiza monteiri $\$ 132$

Hypargos niveoguttatus A2

H. niveoguttatus ogg

Mandingoa nitidula Al13

Vidua orientalis 053

$v$. orientalis 0561

$v$. paradisaea 025

v. paradisaea ABI

$$
\begin{array}{lllll}
6 & 7 & 8 & 9 & 1 \\
0 & 0 & 0 & 0 & 0
\end{array}
$$

00000100000011100000000000111001000000111000000000 00001110000011010010000000111000100000010001110000 00001110000011010010000000111000100000010001110000 00001110000010110010100000111000100000010001100000 01000110000011010000100000110000100000010001000000 01000110000011010000100000110000100000010001000000 00000100000011100000000000111001000000111000000000 000001000000111000000000001110010000001110000000000 00000110010010110100000000111000000000110000100000 10000100000011110001000100111000000000000000000000 00000100000011110001000000111001000000000000010010 00000100000011110001000100111000000000000000010010 10000100000011110001000100111000000001000000010010

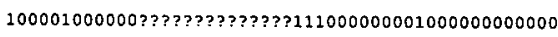
00000100100011000011000010110000000000010001000100 00000100000011000011000010110000000000010001000100 00000100000011000011000010110000000000010001000000 00000100000011000011000010110000000000010001000100 00000100000011010011100000110000000000110000000100 00000100000011010011100000110000000000110000000100 00100000001011010011000000111000000000000000010000 10001100000000010011000000111000000000 ????????????

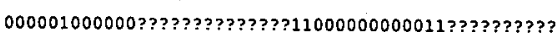
?????100000111110010000000101000000000000000100000

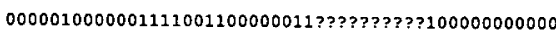
00000100000011010010100001111000010000010000000000 00000100000011010010100000111000010000010000000000 00000100000010010001000000111000010000010000000000 00000101000010000101111000101110000000010001100000 00000101000010000111111000101110000000010001100000 01000101000010000101111000101100000000010001100000 01000101000010000101111000101100000000010001100000 
APpendix 3. Continued.

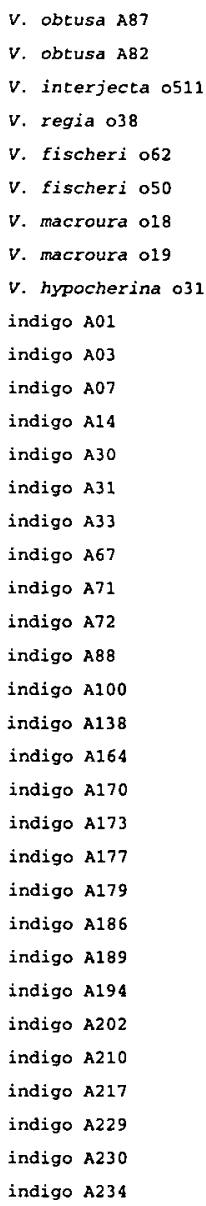

Pytilia afra $\mathrm{A46}$

P. melba grotei A35

P. melba grotei A57

P. melba percivali 056

P. melba citerior 006

P. melba citerior o52

P. phoenicoptera 061

P. hypogrammica 0108

Amadina fasciata 081

L. senegala A74

L. senegala A56

L. senegala A104

L. senegala $A 167$

L. senegala A17I

L. rubricata $A 75$

L. rubricata $A 114$

L. rubricata $A 131$

L. rubricaca ol3

L. rhodopareia A23

L. rhodopareia A41

L. zara 036

L. rara $A 248$

L. Iarvata A145

2. rufopicta 030

Clytospiza monteiri $\mathbf{A} 132$

Hypargos niveoguttatus A24

H. niveoguttatus 099

Mandingoa nitidula $A 113$

V. orientalis 053
01000101000010000101111000101010000000010001101000 01000101000010000101111000101010000000010001101000 00000101000010000101111000101110000000010001100000 00000101000010001101011000101010001000000011000000 ?????101000010001101011000101010001100000011100000 ?????101000010001101011000101010001100000011100000 00000100000010001101011000101010001110110100100001 00000100000010001101011000101000001000010100100001 00000101100010000101011000101000000100000101100000 10100101000010001101011000101010001100000011000000 10100101000010001101011000101010001100000011000000 10100101000010001101011000101010001100000011000000 10100101000010001101011000101010001100000011000000 10100101000010001101011000101010001100000011000000 10100101000010001101011000101010001100000011000000 10100101000010001101011000101010001100000011000000 10100101000010001101011000101010001100000011000000 10100101000010001101011000101010001100000011000000 10100101000010001101011000101010001100000011000000 10100101000010001101011000101010001100000011000000 10100101000010001101011000101010001100000011000000 00110101000010001101011000101010001100000011000000 00100101000010001101011000101010001100000011000000 00100101000010001101011000101010001100000011000000 00100101000010001101011000101010001100000011000000 00100101000010001101011000101000001100000011000000 00100101000010001101011000101000001100000011000000 00100101000010001101011000101010001100000011000000 00100101000010001101011000101000001100000011000000 00100101000010001101011000101010001100000011000000 00100101000010001101011000101010001100000011000000 00100101000010001101011000101010001100000011000000 00100101000010001101011000101010001100000011000000 00100101000010001101011000101010001100000011000000 00100101000010001101011000101010001100000011000000 00100101000010001101011000101010001100000011000000

$$
\begin{array}{lllll}
1 & 1 & 1 & 1 & 1 \\
1 & 2 & 3 & 4 & 5 \\
0 & 0 & 0 & 0 & 0
\end{array}
$$

01110101000000100000011000000000110011100000000000 01100100000000100100001000000000001111100000000000 $0110010000000010010000 ? 000000000001111100000000000$ 01100100000000100100001000000000001111110000000000 01000101000000000100001000010000001011110000000000 01000101000000000100001000010000001011110000000000 01110101000000100000011000000000110011100000001000 01110101000000000011011000000000110011100000001000 01000101000000100000001000000000001000110000000000 01000101000000100100001001000000001011100000000000 01000101000000100100001001000000001011100000000000 01000101000000100100001001000000001010100000000000 01000101000000100100001001000000001011100000000000 01000101000000100100001001000000001011100000000000 01000001110000100100001000000000001010110000001000 01000001110000100100001000000000001010110000001000 01000001110000100100001000000000001010110000001000 01000001110000100100001000000000001010110000001000 01000001000001100100001001100000001010110000001100 01000001000000100100001001100000001010110000001100 01100001000000100000011000001010101001110000001000 ?1100001000000100000011000001010101011110000000000 ?1100001000000????????1????0????001011110000000000 01000101000000100100001010000000101011100000000000

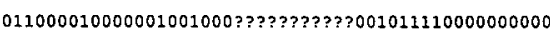
01110101000000100100000000000000001011110001000010 01110101000000100100000000000000001011110001000010 01100111000100100000001010000001001011001100000000 01101101001000000000100100000100101011001000000000

\section{V. orientalis 0561 \\ V. paradisaea 025 \\ V. paradisaea $A 8 I$ \\ V. obcusa $\mathrm{A87}$ \\ V. obtusa A82 \\ v. interjecta o511 \\ v. regia 038 \\ v. fischeri 062 \\ $v$. fischeri o50 \\ V. macroura 018 \\ v. macroura o19 \\ v. hypocherina o31 \\ indigo A01 \\ indigo $\mathrm{A} 03$ \\ indigo $\mathrm{A} 07$ \\ indigo $\mathrm{A} 14$ \\ indigo $A 30$ \\ indigo $A 31$ \\ indigo $\mathrm{A} 33$ \\ indigo $\mathrm{A} 67$ \\ indigo $A 71$ \\ indigo $\mathrm{A} 72$ \\ indigo $A 88$ \\ indigo $A 100$ \\ indigo $A 138$ \\ indigo $A 164$ \\ indigo $A 170$ \\ indigo $A 173$ \\ indigo $A 177$ \\ indigo $A 179$ \\ indigo $A 186$ \\ indigo A189 \\ indigo A194 \\ indigo $\mathrm{A} 202$ \\ indigo A210 \\ indigo $A 217$ \\ indigo A229 \\ indigo $A 230$}

indigo A234

Pytilia afra A46

P. melba grotei A3S

p. melba grotei A57

P. melba percivali o56

P. melba citerior 006

p. melba citerior 052

P. phoenicoptera 061

P. hypogramenica 0108 Amadina fasciata 081

L. senegala A74

L. senegala A56

L. senegala A104

L. Senegala A167

L. senegala $A 171$

L. rubricata A75

L. rubricata A114

L. rubricata $\mathrm{A} 131$

L. rubricata 013

L. rhodopareia A23

L. rhodopareia A41

L. rara 036

L. rara A248

L. larvata A145

L. rufopicta 030

Clytospiza monteiri A132 Hypargos niveoguttatus A24 1000100000000000000100000000000000000000101100001000

01101101001000000000100100000100001111101001000000 01100101001000000000100000000100001011001010000000 01100101001000000000100000000100001011001010000000 01101101001000000000100000000100001011001010000000 01101101001000000000100000000100001011001010000000 01101101001000000000100100000100101011001000000000 01100101000010001000100000000100001111001001000000 01100101000010000100100000000100001111001001000000 0???????????000100100000000100???????????????? 11000111001010010000100100000100001011101001000000 11000101100010011000100000000100101011001000000000 01100101100000011000100000000100001011101000000000 01101101000000001000100010000100001111101001000000 01101101000000001000100010000100001111101001000000 01101101000000001000100010000100001111101001110000 01101101000000001000100010000100001111101001000000 01101001000000001000100010000100001111101001000000 01101101000000001000100010000100001111101001000000 01101101000000001000100010000100001111101001000000 01101101000000001000100010000100001111101001000000 01101101000000001000100010000100001111101001110000 01101101000000001000100010000100001111101001110000 01101101000000001000100010000100001111101001110000 01101101000000001000100010000100001111101001000000 01101101000000001000100000000100001111101001000001 01101101000000001000100000000100000111101001000000 01101101000000001000100000000100001111101001000000 01101101000000001000100000000100001111101001000000 01101101000000001000100000000100001111101001000000 01101101000000001000100000000100001111101001000000 01101101000000001000100000000100001111101001000001 01101101000000001000100000000100001111101001000000 01101101000000001000100000000100001111101001000000 01101101000000001000100000000100001111101001000000 01101101000000001000100000000100001111101001000000 01101101000000001000100000000100001111101001000000 01101101000000001000100000000100000111101001000000 01101001000000001000100000000100001111101001000000 01101101000000001000100000000100001111101001000000

$\begin{array}{lllll}1 & 1 & 1 & 1 & 2 \\ 6 & 7 & 8 & 9 & 0 \\ 0 & 0 & 0 & 0 & 0\end{array}$

11000000000000011000000000000000000001101100000000 11000000000000010110000000000000000000101110001000 11000000000000010110000000000000000000101100001000 11000000000000010110000000100000000000001100101000 11001000000000010110000000000000000000101110001000 11001000000000010110000000000000000000111110001000 11000000000000011001000000000000000001101100000000 1100000000000001100100010000000000000110110000000 10100001100000010010010100000000000000100100001000 11001000000110010010001100000000000000000100000000 10001000000110010010001100000000000000000100000000 10001000000110010010001100000000000000000100000000 11011000000100010000001100000000000000000100000000 $110110000001000100000011000000000000 ? ? ? ? 0100000000$ 10010000000000000010100000000000000000000100000000 10010000000000000010100000000000000000000100000000

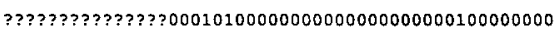
10010000000000000010100000000000000000000100000000 11000000000001100010100000000000100000000100000000 11000000000001100010100000000000100000000100000000 10000000000000110010001000000000100000100100000000 10000000000000110010001000000000100000100100000000 10000000000010010010101100000000000000100100001000 11000000000100010010001100000000000000000110000010 


\section{APPENDIX 3. Continued.}

H. niveoguttatus o99 Mandingoa nitidula A113

V. orientalis 053

$v$. orientalis 0561

$V$. paradisaea 025

V. paradisaea $A B 1$

V. obtusa $\mathbf{A B 7}$

V. obtusa $A B 2$

v. interjecta 0511

V. regia o38

V. fischeri 062

V. fischeri o50

$v$. macroura 018

V. macroura ol 9

v. hypocherina 031

indigo A01

indigo A03

indigo A07

indigo A14

indigo $\mathrm{A} 30$

indigo $A 31$

indigo $A 33$

indigo $A 67$

indigo A71

indigo $A 72$

indigo $A 88$

indigo $A 100$

indigo $A 138$

indigo A164

indigo A170

indigo $\mathrm{A} 173$

inaigo $\mathrm{A177}$

indigo $A 179$

indigo $\mathrm{A} 186$

indigo $\mathrm{A} 189$

indigo A194

indigo $\mathrm{A202}$

indigo $\mathrm{A} 210$

indigo $\mathrm{A} 217$

indigo A229

indigo $\mathrm{A} 230$

indigo A234
10001000000000000010000000000000000000101100001000 11001000000000000110110100000000000000101101000000 11001010000000010010101011000000000010101000000000 11000010000000010110101001000000000010101000000000 11001010000000010110100000000000000011101000000000 11001010000000010110100000000000000011101000000000 11001110000000010110100000000000000011101000000000 11001110000000010110100000000000000011101000000000 11001010000000010110101001000000000010101000000000 11001000011000010010101000001111000010100000000000 11000000011000010110101000001100000010101000000000 $1100000001100001011010100000110000001010 ? ? ? ? ? ? ? ? ? ?$ 11001010000000010110100000000000000010000001011000 11100000000000010110100000000000011110000000000000 11000000000000010110100000001000000001101001000001 11001000010000010100101000001100000011101001010000 11001000010000010100101000001100000011101001010000 11001000010000010100101000001100000011101000010000 11001000010000010100101000001100000011101000010000 11001000010000010100101000001100000011101001010000 11001000010000010100101000001100000011101001010000 11001000010000010110101000011100000011101001010000 11001000010000010100101000001100000001101001010000 11001000010000010110101000011100000011101001010000 11001000010000010100101000001100000001101001010000 11001000010000010100101000001100000001101001010000 11001000010000010100101000001100000011101000010000

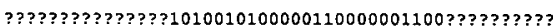
100010000000000101001010000011000000 ????1000000100 10001000000000010100101000001100000011001001000001 10001000000000010100101000001100000001001000010100 11001000010000010000101000001100000011101001010000 11001000010000010100101000001100000011101001010000

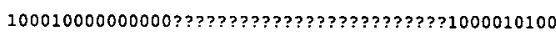
11001000010000010100101000001100000011101001010000 10001000000000010100101000001100000011001000010100 10001000000000010100101000001100000011001001000001 10001000000000010100101000001100000011001000010100 10001000000000010100101000001100000011001000000100 10001000000000010100101000001100000011000000010100 10001000000000010100101000001100000011001000010100 10001000000000010100100000001100000011101000000000 